\title{
Review
}

\section{Direct liquefaction techniques on lignite coal: A review}

\author{
Arif Ali a, Chen Zhao a,b,* \\ a Shanghai Key Laboratory of Green Chemistry and Chemical Processes, School of Chemistry and Molecular Engineering, East China Normal University, \\ Shanghai 200062, China \\ ${ }^{b}$ Institute of Eco-Chongming, East China Normal University, Shanghai 200062, China
}

\section{A R T I C L E I N F O}

\section{Article history:}

Received 22 June 2019

Accepted 2 August 2019

Published 5 March 2020

\section{Keywords:}

Direct liquefaction

Catalytic system

Mechanism of liquefaction

Lignite coal

Fe-based catalyst

\begin{abstract}
A B S T R A C T
With the pressure owing to fossil oil shortages, direct liquefaction is attracting significant attention as a highly efficient and low-cost technique for lignite-to-fuel conversion. In this review, the diverse catalytic systems and mechanisms involved in lignite liquefaction are reviewed. The top five global technologies include IGOR (Germany), HTI (the USA), FFI (Russia), NEDOL (Japan), and Shenhua (China), which have already been applied in industrial scales. Among the five technologies, Shenhua (China) outputs as high as $3000 \mathrm{t} / \mathrm{d}$ using a suspended bed reactor, iron-based catalyst, and rehydrogenated recycled solvents (paraffin, aromatics, etc.). The conversion of lignite is quite difficult due to the presence of ionic bond and non-covalent interactions, such as hydrogen bonding; thus, it is well recognized that the catalytic liquefaction under relatively mild conditions is more feasible than non-catalytic liquefaction. Iron-based catalysts can efficiently facilitate the lignite liquefaction and promote the lignite cracking aided by a hydrogen-donor solvent; thus, they have attracted interest from researchers globally. The different liquefaction mechanisms of lignite including free radical, oxidation, alkanolysis, and hydrogenation lead to the corresponding products: preasphaltene and asphaltene, mixed carboxylic acids, mixed esters and ethers, and cyclic compounds, respectively. Therefore, the catalytic system of the lignite liquefaction process would be accordingly optimized and modified to afford different products.
\end{abstract}

(C) 2020, Dalian Institute of Chemical Physics, Chinese Academy of Sciences. Published by Elsevier B.V. All rights reserved.

\section{Introduction}

Lignite together with renewable biomasses such as oils, lipids, and lignin is a promising bio-resource for generating fuel and chemicals via pyrolysis and liquefaction [1-14]. Lignite can produce a high number of liquefied products via direct liquefaction [13]. The enormous reserves of lignite coals can be converted into transportation fuel via the direct liquefaction process of coal to overcome the deficiency of petroleum oil [14]. Thus, the macromolecular structure of lignite can be decomposed effectively into relatively small molecular-weight liquid compounds by applying the catalytic liquefaction process in the presence of catalysts that can increase the yield of the low molecular-weight fractions [15]. In this way, the catalytic liquefaction process can reduce the lignite coal structure and afford a large number of organic compounds at large scales compared to the case with non-catalytic liquefaction. Additives and treatments that have been found to be useful supplements or substitutes for more conventional processes will be briefly listed, while the body of the review will be devoted to more conventional techniques. The effects of various additives are reported, and it is revealed that the addition of tourmaline into

\footnotetext{
* Corresponding author. E-mail: czhao@chem.ecnu.edu.cn

This work was supported by the National Key Research and Development Program of China (2016YFB0701100), the National Natural Science Foundation of China (21573075), Institute of Eco-Chongming (ECNU-IEC-201902) and the Recruitment Program of Global Young Experts in China. DOI: S1872-2067(19)63492-3 | http://www.sciencedirect.com/science/iournal/18722067 | Chin. I. Catal., Vol. 41, No. 3, March 2020
} 
lignite with other additives, including wheat straw and plastic waste, enhances the total conversion as well as improves the quality and yield of oil during the liquefaction $[16,17]$. The quality and yield of the liquefied products can be further improved by the co-liquefaction of lignite coal with the direct liquefied residue due to the interactive effect between lignite and the direct liquefied residue [18]. Lignite coal contains alkali and alkaline earth metal species with discrete minerals. The addition of sodium carbonate on conventional iron catalysts enhances the conversion of asphaltene to oils and promotes hydrolyzation as well as depolymerization reactions $[13,19]$. The hydrothermal treatment of some lignite coals leads to the cleaving of certain classes of covalent bonds during pyrolysis, thereby increasing the tar yield and enhancing the hydrogen transfer between water and the lignite coal structure [20]. In particular, studies have determined the effect of different parameters, including the hydrothermal treatment, on direct coal liquefaction (DCL) in the presence of tetralin and iron sulfide catalysts [21a].

The direct liquefaction of coal and lignite can play a significant role in the production of liquid fuels for many developing countries, such as China, which has large coal and lignite reserves but less crude oil [22]. The conventional approach of simply heating the lignite in a solvent with appropriate catalysts in a suitable gaseous atmosphere is not the only method of obtaining high oil yields. Pre-treatment by various methods has been found to be beneficial. The degradative solvent extraction method can be employed to upgrade various types of low-ranking coal, including lignite [14], while thermal degradation of lignite at a high temperature can produce various organic products [21b]. Briefly, we summarized related review papers in Table 1 to obtain more knowledge on lignite and coal, their structures, pyrolysis, gasification, drying, distributions, liquefaction, etc. The most recent review on the liquefaction of coal was presented by Shui et al. [36]; however, it does not cover the oxidation, reduction scope of lignite, and mechanism for the formation and classification of the products. Therefore, an overview of the mechanisms of lignite coal liquefaction, including oxidation, hydrocracking via free radicals, carbocation formation, alkanolysis, as well as their product classifications is required, which is provided herein.

In this review, the mechanism of the direct liquefaction of lignite is elucidated under the various conditions that have been tested to maximize the yields of useful products. Furthermore, the usages of different technologies are compared. In addition, a comparative study is conducted on the catalytic and non-catalytic liquefactions under different conditions. The influences of catalysts, temperature, pressure, and solvents are discussed, and the well-defined products formed via solvent-fraction are classified into distinct categories based on the mechanism involved during the direct liquefaction.

\section{Brief description of the trends in the chemical composition of lignite coal}

Noticeably, lignite is a low-ranking coal with different complex structures according to its origin, type, and rank. Due to the complexity of the structure and the difficulty associated with separating the liquefaction products, lignite liquefaction is still at the developmental stage; the investigation of lignite using a simulated model provides an efficient way gaining an in-depth understanding of the lignite liquefaction process. SIGNATURE is an extensively applied software that can be employed to automatically construct molecular diverse lignite coal structures when data inputs are available, and various computational molecular representations have been designed with it [33]. As shown in Table 2, the average $\mathrm{H} / \mathrm{C}$ ratio of lignin-derived coal is 1.102, while those of brown coal and lignite coal are 0.887 and 0.901 , respectively. This is attributed, speculatively, to the continual decomposition in the formation process; the sources also have a significant effect. In conclusion, the liquefaction conditions should be optimized such that different ranks, composition, and molecular models of lignite are considered.

\section{Direct liquefaction of lignite}

The study of the direct liquefaction of lignite from a mecha-

Table 1

Overview of the main contributions regarding coal and lignite in the following review papers.

\begin{tabular}{lr}
\hline Main contributions related to coal and lignite of some review papers & Ref. \\
\hline $\mathrm{CO}_{2}$ sequestration for Victorian brown coal, coal mass properties, mathematical models, coal gas permeability, and gas sorption & {$[22]$} \\
Water interactions in brown coal, physical and chemical changes in coal structure, and polar functional groups & {$[23]$} \\
Coal-to-liquid, coal resources, synthetic liquid fuels, and projected coal demand & {$[24]$} \\
Compaction and transformation of peat into lignite and coal & {$[25]$} \\
Distribution, characterization, utilization of lignite, gasification, pyrolysis, and lignite liquefaction & {$[26]$} \\
Gasification of biomass and lignite in detail via pyrolysis. Char and volatiles & {$[27]$} \\
Coal-derived chemicals, coal pyrolysis, engineering plastics, and carbochemicals & {$[28]$} \\
Differential thermal analysis, combustion, and pyrolysis of coal and lignite & {$[29]$} \\
Lignite drying technologies, fuel preparation, and processing & {$[30]$} \\
Combustion, gasification, and dewatering of lignite & {$[31]$} \\
Pyrolysis and gasification process of Victorian brown coal, and volatile-char interactions & {$[32]$} \\
Coal structures and coal molecular models & {$[33]$} \\
Underground gasification of lignite from polish deposits & {$[34]$} \\
Coal demineralization, acid and alkali leaching for ultraclean coal and HPC & {$[35]$} \\
Direct liquefaction processes, catalysts, co-liquefaction, and biomass & {$[36]$} \\
Indirect coal liquefaction, process simulation results, and synthetic fuel & {$[37]$} \\
Direct liquefaction of lignite coal, liquefied products, mechanism for liquefaction products and classification & Recent \\
\hline
\end{tabular}


Table 2

Distribution of the molecular representation units of lignite coal-based on their different ranks, carbon percentage, oxygen percentage, hydrogen to carbon ratio, and the average (Av) hydrogen to carbon ratios.

\begin{tabular}{|c|c|c|c|c|c|c|c|}
\hline Rank of lignite & Type of model & Molecule & $\mathrm{C} \%$ & $0 \%$ & $\mathrm{H} / \mathrm{C}$ & Av. H/C & Ref. \\
\hline \multirow[t]{3}{*}{ Lignin derived coal } & Millya model & $\mathrm{C}_{122} \mathrm{H}_{146} \mathrm{O}_{23} \mathrm{~N}_{2} \mathrm{SM}_{4}$ & 68.7 & 17.2 & 1.196 & 1.102 & {$[38]$} \\
\hline & Hatcher model & $\mathrm{C}_{108} \mathrm{H}_{104} \mathrm{O}_{32}$ & 67.8 & 26.8 & 0.962 & & [39] \\
\hline & Tromp model & $\mathrm{C}_{161} \mathrm{H}_{185} \mathrm{O}_{48} \mathrm{~N}_{2} \mathrm{~S}_{1} \mathrm{M}_{4}$ & 63.6 & 25.3 & 1.149 & & [40] \\
\hline \multirow{5}{*}{$\begin{array}{l}\text { Brown coal } \\
\text { (lignite B) }\end{array}$} & Wolfrum model & $\mathrm{C}_{227} \mathrm{H}_{183} \mathrm{O}_{35} \mathrm{~N}_{4} \mathrm{~S}_{3} \mathrm{CaFeAl}$ & 73.0 & 14.9 & 0.806 & 0.887 & {$[41]$} \\
\hline & Vu model & $\mathrm{C}_{100} \mathrm{H}_{80} \mathrm{O}_{28}$ & 69.4 & 25.9 & 0.800 & & {$[42]$} \\
\hline & Domazetis model & $\mathrm{C}_{258} \mathrm{H}_{256} \mathrm{~N}_{2} \mathrm{O}_{78} \mathrm{~S}$ & 66.4 & 26.8 & 0.922 & & {$[43]$} \\
\hline & Kumagai model & $\mathrm{C}_{21} \mathrm{H}_{20} \mathrm{O}_{7}$ & 65.6 & 29.1 & 0.952 & & {$[44]$} \\
\hline & Huttinger model & $\mathrm{C}_{270} \mathrm{H}_{240} \mathrm{O}_{90} \mathrm{~N}_{3} \mathrm{~S}_{3} \mathrm{M}_{10}$ & 61.3 & 27.2 & 0.889 & & [45] \\
\hline \multirow{6}{*}{$\begin{array}{l}\text { Lignite coal } \\
\text { (lignite A) }\end{array}$} & Iwata model & $\mathrm{C}_{19} \mathrm{H}_{14} \mathrm{O}$ & 88.3 & 6.20 & 0.736 & 0.901 & {$[46]$} \\
\hline & Patrakov model & $\mathrm{C}_{727} \mathrm{H}_{790} \mathrm{~N}_{2} \mathrm{~S}_{4} \mathrm{O}_{36}$ & 85.7 & 5.60 & 1.086 & & [47] \\
\hline & Krevelen model & $\mathrm{C}_{135} \mathrm{H}_{96} \mathrm{O}_{9} \mathrm{NS}$ & 84.9 & 7.50 & 0.710 & & [48] \\
\hline & Shinn model & $\mathrm{C}_{661} \mathrm{H}_{561} \mathrm{~N}_{4} \mathrm{O}_{74} \mathrm{~S}_{6}$ & 79.9 & 11.9 & 0.840 & & [49] \\
\hline & Philip model & $\mathrm{C}_{115} \mathrm{H}_{125} \mathrm{O}_{17} \mathrm{NS}$ & 75.5 & 14.9 & 1.087 & & {$[50]$} \\
\hline & Wender model & $\mathrm{C}_{42} \mathrm{H}_{40} \mathrm{O}_{10}$ & 71.6 & 22.7 & 0.952 & & [51] \\
\hline
\end{tabular}

nistic point of view is more complicated than that for a higher-ranking coal because the structure of lignite is considerably complex. Lignite possesses a relatively wide range of functional groups, particularly oxygen groups; therefore, it undergoes various types of reactions, such as cross-linking, involving these functional groups [52]. Thus, cross-linking/repolymerization reactions are considerably more important at high temperatures for low-ranking coal, such as lignite, than for bituminous coals [53]. Nevertheless, to obtain useful fuels or low-molecular-weight chemicals from low-ranking coals in reduction reactions, high reducing gas pressures and active catalysts to stabilize small fragments have been found to be indispensable [54-56]. Suitable sufficiently cheap catalysts are mainly iron-based (hydroxide, sulfate, pyrite), although other metals and their oxides, halides, or sulfides have been used [57]. To minimize the catalyst deactivation, it is desirable to use coals containing low concentrations of nitrogen and sulfur [56] and to remove inorganic components and other impurities prior to the reaction [58]. The presence of a hydrogen donor solvent assists in reducing the required residence time [59] and the temperature required to obtain high yields of small-molecular-weight products. The importance of a high reducing gas pressure, active catalysts, and a suitable hydrogen donor solvent is exemplified in the practical processes that have been tested. Interestingly, direct liquefaction is one of the important processes for obtaining valuable products from coal and low-ranking coals, such as lignite. The DCL process produces considerably high-variety and efficient products at low temperatures compared to the indirect coal liquefaction process. Generally, Fig. 1 shows the distinct difference between the direct and indirect liquefaction processes. Importantly, DCL consists of many steps for the conversion of coal to PA (pre-asphaltenes) and AS (asphaltenes), and subsequently to gas, oil, and residue [60].

\section{Used catalytic systems involved in direct liquefaction in the industry}

In the early 1920s, Friedrich Bergius introduced the commercial process of DCL in Germany and England. In addition to the Bergius process, other processes such as the high-pressure catalytic hydrogenation process and Pott-Bioche solvent dissolving process were introduced before World War II [36]. Recently, five technologies with the capability to carry out large-scale direct liquefaction have been utilized. These technologies are integrated gross oil refinery (IGOR), hydration technology innovation (HTI), FFI, new energy and industrial technology development organization liquefaction (NEDOL), and Shenhua (ST). IGOR and HTI have been used in Germany and the USA, respectively. Similarly, FFI, ST, and NEDOL have been used in Russia, the Shenhua province of China, and Japan, respectively.

These DCL technologies require high hydrogen pressures (15-30 MPa), high temperatures $\left(450-500{ }^{\circ} \mathrm{C}\right)$, and a suitable catalyst and solvent [36]. The pilot plant of the NEDOL process consists of four sections. The first section is a coal-slurry preparation section containing a pulverizer and drier for coal. The second section mixes the coal with the solvent. The third section is the liquefaction section, which performs liquefaction in the pre-heater. The fourth section is a high-pressure solvent hydrogenation section using a solvent hydrogenation reactor along with six beds of a Ni/Mo catalyst. The liquefaction section of the reactor system is comprised of three bubble column reactors, which lie in series [62]. The NEDOL process usually employs pyrite as the catalyst and the hydrogenation of recycled oil to obtain a high oil yield of $58 \mathrm{wt} \%$ of daf (dry and ash-free) under mild temperature $\left(452-462{ }^{\circ} \mathrm{C}\right)$ and pressure (16.8-18.8 $\mathrm{MPa}$ hydrogen) conditions. In addition, a plug-flow-type reactor designed for the EDS (Exxon Donor Process) has a height of $47.5 \mathrm{~m}$ and a diameter of $2.9 \mathrm{~m}$ [63]. Another backmix-type reactor for the proposed SRC-II (solvent refined coal-11) process has a height of $20.4 \mathrm{~m}$ and diameter of $3.35 \mathrm{~m}$. Nevertheless, the capacity of the backmix-type reactor is less than that of the plug-flow-type reactor [64]. 
The main distinguishing characteristic of the NEDOL process is the downstream solvent hydrogenation section. In the Kashima pilot plant, the recycled oil equilibrated after the regular operation of $1000 \mathrm{~h}$ was divided into fractions of 12 narrow boiling pointcuts by means of ASTM (American society for testing and materials) D 2829. In addition, various physical properties including boiling point, heat of vaporization, vapor pressure, specific heat capacity, specific gravity, molecular weight, and thermal conductivity of the liquefied oil can be determined for the fractions in the NEDOL process, and the data is stored in the reaction simulator [65]. The flow chart of the NEDOL process is shown in (Fig. 2) [61]. Notably, the oil yields from DCL processes depend on the rate of heating as well as the final temperature, at which the best results are obtained, which can be termed as TPL (temperature-programmed liquefaction). TPL is more effective than rapidly heated liquefaction for low-ranking coals [66] as it affords $77 \%-81 \%$ conversion at $400{ }^{\circ} \mathrm{C}$ compared to only $71 \%-72 \%$ for the rapid heating liquefaction under similar conditions [67]. Similarly, further study reveals that Huang and Schobert also observed the significant effects of TPL and provided a detailed explanation [68].

It should be acknowledged that catalysts can increase the capacity of the direct liquefaction process. The Shenhua II technology from China using a suspended bed reactor exhibits the highest capacity over iron-based catalysts. The DCL plant manufactured in Inner Mongolia, located at the Shenhua province in China, was the first commercial DCL plant since World War II $[69,70]$. The Shenhua DCL is an efficient process, which gives $90 \%-92 \%$ coal conversion using $5 \%-7 \%$ hydrogen. This commercial-scale plant was manufactured in August 2004 with a capacity of 3,000 tons per day. This plant could produce about one million tons of synfuel per year, and it successfully produced liquid oils by trial run in December 2008. Due to this progress, China became the only country to have achieved a large-scale direct coal-to-liquid production at 1 million tons per

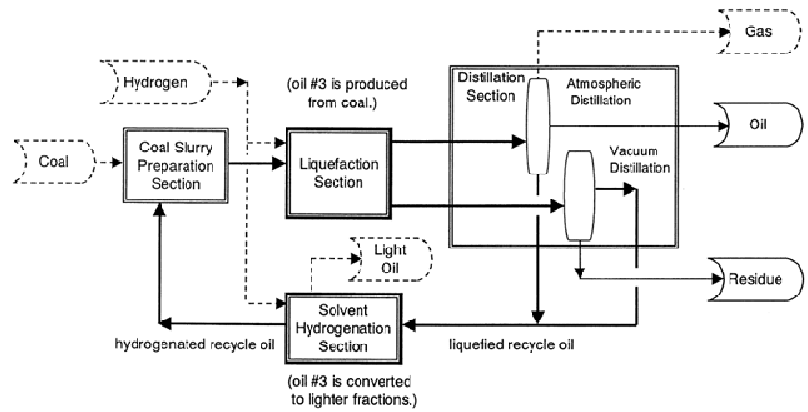

Fig. 2. Flow chart of the NEDOL process. Solid lines, streams containing oil \#3; broken lines, streams with no oil \#3, reproduced from Ref. [61].

year. It can be illustrated that the hydrogen donor solvent and metallic sulfide catalysts are crucial for the DCL process. Therefore, the hydrogen donor capability of some solvents is promoted easily due to the existence of hydrogen sulfide in the gas phase [71]. Table 3 illustrates the capacities of all the well-known technologies $[36,55,62,69]$, including the five listed above (CT- 5 is the same as FFI). Table 3 further suggests that iron-based catalysts can provide the preferred route to achieving high liquefaction yields. The other processes that have not been commercialized to date can be described briefly. Solvent refined coal processes (SRC-I and SRC-II) have been developed based on the Bergius process and Pott-Bioche solvent dissolving process (see Table 3 ) $[36,55,62,69]$. The IGOR process was carried out in a fixed bed reactor in the presence of red-mud over Ni-Mo/ $/ \mathrm{Al}_{2} \mathrm{O}_{3}$. The detailed study on IGOR reveals that its capacity is $200 \mathrm{t} / \mathrm{d}$. Further research shows that the development of the Shenhua DCL process progressed from a BSU (bench-scale unit) to a pilot-scale PDU (process development unit). The Shenhua DCL process was developed starting with a BSU (bench-scale unit) of $0.1 \mathrm{t} / \mathrm{d}$ capacity constructed by the end of 2003. The BSU was operated successfully for about 5000

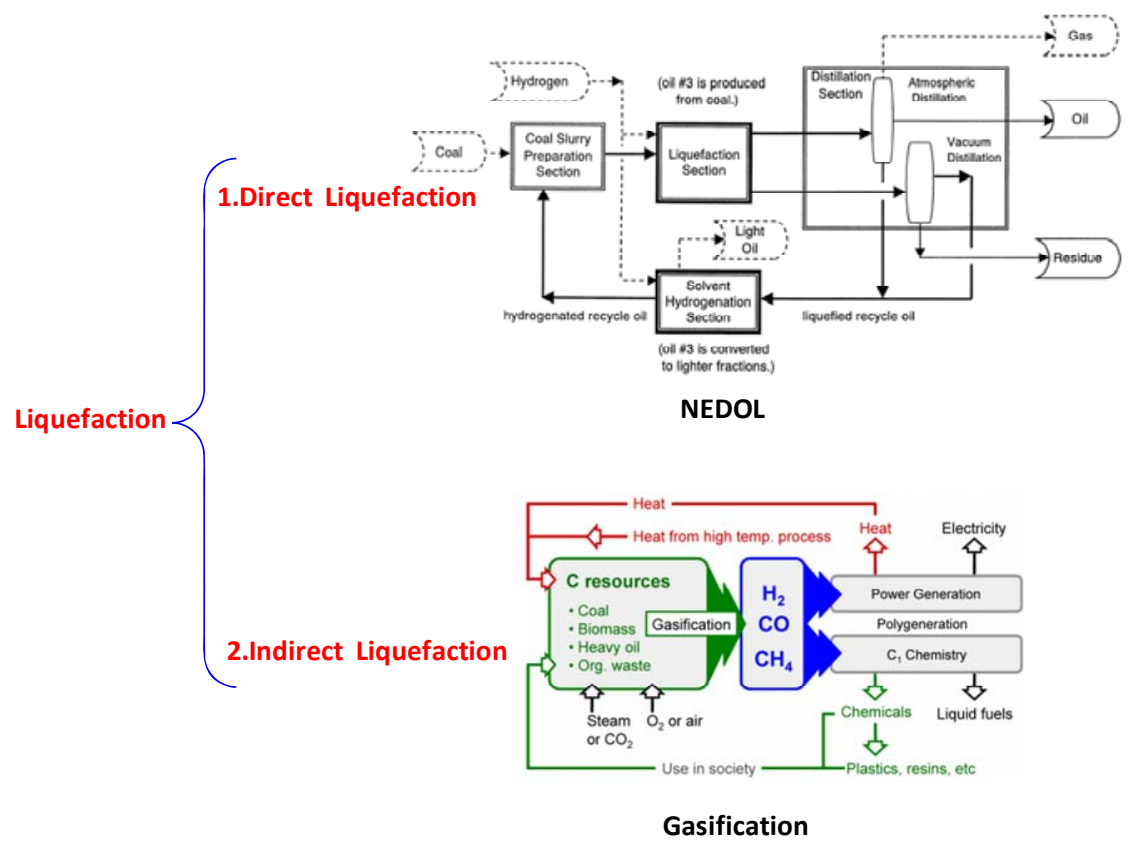

Fig. 1. Pictorial scheme showing the classification of the liquefaction of diverse lignite coals, reproduced from Refs. [27,61]. 
Table 3

Summary of the major DCL processes developed globally. Here, "a" represents the first-stage; "b" indicates the second-stage, and "c" shows the recycled solvent for the catalytic hydrogenation.

\begin{tabular}{|c|c|c|c|c|c|}
\hline Country & Process & Reactor & Catalyst & Capacity $(\mathrm{t} / \mathrm{d})$ & Time \\
\hline \multirow{6}{*}{ USA } & SRC-1 & Coal slurry dissolver & - & 6 & 1974 \\
\hline & SRC-11 & Coal slurry dissolver & - & $50 / 25$ & 1974-1981 \\
\hline & EDS & Entrained bed & $\mathrm{Ni} / \mathrm{Mo}^{\mathrm{c}}$ & 250 & 1979-1983 \\
\hline & H-Coal & Fluidized bed & $\mathrm{Co}-\mathrm{Mo} / \mathrm{Al}_{2} \mathrm{O}_{3}$ & 600 & 1979-1982 \\
\hline & CTSL & Fluidized bed & $\mathrm{Ni} / \mathrm{Mo}$ & 2 & 1985-1992 \\
\hline & HTI & Suspended bed & GelCat ${ }^{\mathrm{TM}}$ & 3 & $1990 \mathrm{~s}$ \\
\hline \multirow{2}{*}{ Germany } & IGOR & Fixed bed & Red-muda, $\mathrm{Ni}-\mathrm{Mo} / \mathrm{A}_{12} \mathrm{O}_{3} \mathrm{~b}$ & 200 & 1981-1987 \\
\hline & PYROSOL & Counter-current & - & 6 & 1977-1988 \\
\hline \multirow{2}{*}{ Japan } & $\mathrm{BCl}$ & Fixed bedb & Fe-baseda, $\mathrm{Ni}-\mathrm{Mo} / \mathrm{A}_{12} \mathrm{O}_{3} \mathrm{~b}$ & 50 & 1986-1990 \\
\hline & NEDOL & Fluidized bed & Nature pyrite & 150 & 1996-1998 \\
\hline UK & LSE & $\begin{array}{l}\text { Stirred tank-type } \\
\text { Fluidized bed }^{\mathrm{a}}\end{array}$ & - & 2.5 & 1983-1985 \\
\hline USSR & CT-5 (FFI) & - & Mo & 7 & 1986-1990 \\
\hline \multirow{2}{*}{ China } & Shenhua 1 & Suspended bed & Fe-based & 6 & $2002-$ \\
\hline & Shenhua 11 & Suspended bed & Fe-based & 3000 & 2004- \\
\hline
\end{tabular}

working hours. Thereafter, in September 2004, a PDU (process development unit) was built, operating at a scale of up to 6 tons per day. These experiments were significant steps in the industrialization of the Shenhua process $[36,69]$.

The experimental operating parameters and the results for some major DCL processes, globally, are shown in Table 4 $[36,55,62,69]$, where the direct liquefaction of Shenhua and Xianfeng lignites under different technologies is demonstrated. Moreover, Xianfeng lignite under IGOR has the highest conversion $(97.5 \%)$ and the least residues with higher hydrogen consumption compared to the Shenhua lignite coal obtained using other processes.

\section{Catalytic and non-catalytic liquefaction techniques of lignite on a laboratory scale}

Herein, we classify DCL into two categories whether catalysts are present or not: catalytic liquefaction and non-catalytic liquefaction. Moreover, catalytic liquefaction can further be categorized into two types: the catalytic liquefaction in the presence of iron-based catalysts (iron-catalyzed liquefaction) and the catalytic liquefaction in the absence of iron-based catalysts. Thus, the different products obtained from the catalytic liquefaction can be summarized in the presence of different catalysts and various solvents under different temperature and pressure conditions.

\section{Table 4}

DCL processes: HTI, IGOR, NEDOL, and Shenhua for Xianfeng and Shenhua lignite coal.

\begin{tabular}{lcccc}
\hline Process & HTI & IGOR & NEDOL & Shenhua \\
\hline Lignite origin & Shenhua & Xianfeng & Shenhua & Shenhua \\
Temperature $\left({ }^{\circ} \mathrm{C}\right)$ & $440-450$ & 470 & 465 & 455 \\
Pressure $(\mathrm{MPa})$ & 17 & 30 & 18 & 19 \\
Space velocity (t/m $/ \mathrm{h})$ & 0.24 & 0.60 & 0.36 & 0.70 \\
Conversion (\%, daf lignite coal) & 93.5 & 97.5 & 89.7 & 91.7 \\
$\mathrm{C}_{4}+$ oils $(\%$, daf lignite coal) & 67.2 & 58.6 & 52.8 & 61.6 \\
Residues (\%, daf lignite coal) a & 13.4 & 11.7 & 28.1 & 14.7 \\
Hydrogen consumption (\%) & 8.7 & 11.2 & 6.1 & 5.5 \\
\hline
\end{tabular}

a Represents ash, spent catalyst, and un-converted lignite.
The abbreviations for various products in Tables 5-7 are HS (hexane soluble), AS (asphaltene), HC (hydrocarbons), THFIS (tetrahydrofuran insoluble), THFS (tetrahydrofuran soluble), WS (water soluble), PA (pre-asphaltene), TS (toluene soluble), and TIS (toluene insoluble). For the catalysts, FC (iron-based catalysts), NC (sodium based catalysts), AAH (acetic anhydride), and [Bmim]Cl (1-butyl, 3-methylimidazolium chloride). Similarly, for the lignite types, SL (Shengli lignite), XLTL (Xiaolongtan lignite), and SLLR (Shengli lignite residue). For biomass, WS (wheat straw). The abbreviations for coal are HN (Huainan bituminous coal), SH (Shenhua bituminous coal), YZ (Yanzhou bituminous coal), and DCL (direct coal liquefaction).

\subsection{Catalytic liquefaction}

\subsubsection{Catalytic liquefaction in the presence of iron-based catalysts}

Table 5 shows the summarized data for the iron-catalyzed liquefaction. The applied lignite and coal exhibited improved conversion in the presence of iron-based catalysts and tetralin as the solvent. The high efficiency owing to iron-based catalysts can be achieved via two pathways. Firstly, iron-based catalysts can split molecular hydrogen into free hydrogen radicals, which are unstable, more reactive, and cause rapid hydrocracking. Secondly, iron-based catalysts can catalyze the fast dehydrogenation of tetralin to release hydrogen, and then initiate the rapid hydrocracking. Thus, Table 5 shows that the conversion of lignite proceeds well in the presence of iron-based catalysts and tetralin as the hydrogen donor solvent $[72,73]$. In the absence of hydrogen, tetralin provides hydrogen for the hydrocracking reactions during the liquefaction due to the influence of iron-based catalysts.

\subsubsection{Catalytic liquefaction in the presence of other catalysts}

Other than iron, other catalysts afforded good conversion in some cases, although often at high hydrogen pressures (13 MPa [80] and $20 \mathrm{MPa}$ [88]), as shown in Table 6. Among these catalysts, $\mathrm{NaOH}$ [80], [Bmim] $\mathrm{Cl}$ [82], $\mathrm{Ni}-\mathrm{B} / \mathrm{SiO}_{2}$ [83], and fumed 
Table 5

Summarized data of the catalytic liquefaction in the presence of iron-based catalysts.

\begin{tabular}{|c|c|c|c|c|c|c|c|}
\hline Lignite types $\mathrm{L}=$ Lignite & Catalysts & $T\left({ }^{\circ} \mathrm{C}\right)$ & $\begin{array}{c}\mathrm{H}_{2} \\
(\mathrm{MPa})\end{array}$ & Solvent & $\begin{array}{c}\text { Conv. } \\
(\%)\end{array}$ & Products & Ref. \\
\hline Xiaolongtan L & $\mathrm{FeS}$ & 400 & 5 & Tetralin & 92 & AS aromatics & {$[13]$} \\
\hline Rice straw, brown coal & $\mathrm{FeOOH} / \mathrm{S}$ & 400 & 2 & 1-MN and Tetralin & 100 & Aliphatic and aromatic HC & {$[14]$} \\
\hline Shengli L & Fe-S/ZSM-5 & 300 & 4 & Cyclohexane & 61 & Alkanes, arenes, etc. & {$[15]$} \\
\hline Jingou L, plastic waste and WS & $\mathrm{FeS}, \mathrm{Fe}_{2} \mathrm{O}_{3}$ and $\mathrm{S}$ & $280-320$ & $2-5$ & Tetralin & 80 & Oil and gas yields & [16] \\
\hline Hulunbeier L, Shendong coal & $\mathrm{FeS}$ & 550 & & & 71 & Tar and n-hexane soluble products & [18] \\
\hline Shenhua coal (DCLR) & FC-NiMo $/ \mathrm{Al}_{2} \mathrm{O}_{3}$ & 450 & 14 & Tetralin & 99 & THFS and THFIS products & [19] \\
\hline Catalan L & Fe-based catalyst & 380 & & Tetralin & 85 & Aromatic oils & [72] \\
\hline Two Turkish L & $\mathrm{Fe}_{2} \mathrm{O}_{3}, \mathrm{MoO}_{3}$ and $\mathrm{Mo}(\mathrm{CO})_{6}$ & $350-425$ & & Tetralin & 70 & Sulfur containing products & [73] \\
\hline Shengli L & FC and NC & 400 & 4 & Tetralin & 100 & THFI, PA, HS, and AS & {$[74]$} \\
\hline Shengli L (SL) & $\mathrm{FeS}$ and $\mathrm{CaO}$ & 400 & $0.5-5$ & Methanol, Tetralin & 82 & HIS, TS, TIS, THF, HS, AS, and PA & {$[75]$} \\
\hline Shengli L and corn stalk & $\mathrm{Fe}_{2} \mathrm{O}_{3}$ and $\mathrm{S}$ & $360-420$ & 7 & Tetralin & 85 & PA, AS, oil, and gas & [76] \\
\hline (XLT, S)L, (HN,SH, and YZ & $\mathrm{FeS}$ & 350 & 3 & Tetralin & 73 & Oil and AS & {$[77]$} \\
\hline Kansk-Achinsk L & Fe-ores & 380,430 & 5 & Tetralin & 90 & Maltenes and AS & {$[78]$} \\
\hline Elbistan $\mathrm{L}$ and biomass & $\mathrm{Fe}_{2} \mathrm{O}_{3}, \mathrm{MoO}_{3}$, and others & 400 & 2 & Tetralin & 91 & Naphthalene, biphenyl, etc. & [79] \\
\hline
\end{tabular}

Table 6

Summarized data for the catalytic liquefaction in the presence of other catalysts.

\begin{tabular}{|c|c|c|c|c|c|c|c|}
\hline Lignite types L=Lignite & Catalysts & $T\left({ }^{\circ} \mathrm{C}\right)$ & $\begin{array}{c}\mathrm{H}_{2} \\
(\mathrm{MPa})\end{array}$ & Solvent & $\begin{array}{c}\text { Conv. } \\
(\%)\end{array}$ & Products & Ref. \\
\hline Shengli L & $\mathrm{NaOH}$ & 300 & 13 & Methanol & 98 & THFS, TS, HS, WS & {$[80]$} \\
\hline Shengli L & $\mathrm{Ni}-\mathrm{Mo}-\mathrm{S} / \mathrm{Al}_{2} \mathrm{O}_{3}$ & 380 & 5 & Methanol/Ethanol etc & 66 & HS, AS, PA, THF soluble products & [81] \\
\hline Shengli L & {$[\mathrm{Bmim}] \mathrm{Cl}$} & $300-800$ & - & Water & 89 & Oils and liquids. & {$[82]$} \\
\hline Shengli L residue (SLLR) & $\mathrm{Ni}-\mathrm{B} / \mathrm{SiO}_{2}$ & 140 & 0.7 & Methanol & 88 & Aromatic and aliphatic compounds & [83] \\
\hline Xialongtan L (XLTL) & AAH & $30-60$ & - & Methanol & 66 & Carboxylic acids & [84] \\
\hline Mengen L & $\mathrm{Co}-\mathrm{Mo} / \mathrm{Al}_{2} \mathrm{O}_{3}$ & $360-440$ & $1.5-1.6$ & Anthracene & 65 & Oils, AS, and PA & {$[85]$} \\
\hline Beypazari L & $\mathrm{NiCl}_{2}-\mathrm{KCl}-\mathrm{LiCl}$ & $300-360$ & - & Tetralin & 72 & Oils, asphatols, and AS & [86] \\
\hline Fushun L & Fungus AH & 26.5 & - & - & 45 & Aromatics & [87] \\
\hline Brown coal and bio-coal & $\mathrm{Co} / \mathrm{SiO}_{2}$ or $\mathrm{Ni} / \mathrm{TiO}_{2}$ & 455 & 20 & Tetralin & 71 & Oils & [88] \\
\hline Miocene-aged L humic acid & Fumed silica & $600-800$ & - & - & 80 & Naphthalene, biphenyl, etc. & [89] \\
\hline Tunçbilek L & $\mathrm{Cu}(\mathrm{OH})_{2}$ & 170 & - & Water & & Guaiacyl nucleus & [90] \\
\hline Xianfeng L & $\mathrm{H}_{2} \mathrm{O}_{2}$ & 320 & 2 & Methyl Naphthalene & 65 & Various organic compounds & [91] \\
\hline
\end{tabular}

silica [89] were quite effective catalysts. $\mathrm{Ni}-\mathrm{B} / \mathrm{SiO}_{2}$ exhibited efficient conversion at a low temperature and pressure in methanol (solvent) [83]. Notably, an interesting phenomenon occurs during the liquefaction of Shengli lignite with $\mathrm{NaOH} /$ methanol. $\mathrm{NaOH}$ reacts with methanol to produce hydrogen, which is essential for coal hydrogenation to achieve efficient conversion (98\%) [80]. Generally, the liquefaction and conversion ability over other catalysts tend to be lower than those for iron-based catalysts; however, non-conventional solvents and catalysts can afford excellent results. The lesser activity of some catalysts can be understood in light of the explanation of the activity of iron-based catalysts. Similarly, other catalysts might have relatively low hydrogen splitting activities toward molecular hydrogen and poor ability to extract hydrogen from tetralin or other solvents.

\subsubsection{Catalytic liquefaction in the presence of iron-based catalysts}

\subsection{Non-catalytic liquefaction}

The non-catalytic liquefaction data obtained have been summarized in Table 7. Noteworthily, tetralin has been used as a solvent for both non-catalyzed and catalyzed liquefaction processes $[16,95,97,99,101]$.

\subsection{Summary of the trends in laboratory experiments}

Our summarized data discloses that iron-based catalysts are generally more effective in achieving a high conversion to liquid products than other catalysts or with no catalyst at all. The average conversion in Table 7 is $60.4 \%$ under $4.7 \mathrm{MPa} \mathrm{H}_{2}$ at $550{ }^{\circ} \mathrm{C}$, and the average conversion in Table 6 is $75 \%$ under 8 $\mathrm{MPa} \mathrm{H}_{2}$ at $367^{\circ} \mathrm{C}$ compared to $86.7 \%$ under $4.4 \mathrm{MPa}_{2}$ at 355 ${ }^{\circ} \mathrm{C}$ for the iron-based catalyzed liquefaction under tetralin (see Section 5.1.1 above). This averaging procedure can only give a general indication of trends because it neglects other factors, such as the effects of the heat-up rate (see the discussion above of TPL in Section 4), reaction time, coal properties, and autoclave geometry. Notably, the comparison of the averages for iron-catalyzed and non-catalyzed liquefaction suggests an important effect of iron catalysts on the liquefaction conversion. This does not imply that non-catalyzed liquefaction is always a low-conversion process; Spanish lignite [97] and Yunnan brown coal [99] achieved good conversion in tetralin without a catalyst, at a moderate hydrogen pressure. Tetralin as a solvent has been found to afford high conversions with iron-based catalysts in laboratory-based experiments and has also often been used with other catalysts or in non-catalyzed liquefaction. 
Table 7

Summarized data of the non-catalytic liquefaction in the absence of catalysts.

\begin{tabular}{|c|c|c|c|c|c|c|}
\hline Lignite types L=Lignite & $T\left({ }^{\circ} \mathrm{C}\right)$ & $\mathrm{H}_{2}(\mathrm{MPa})$ & Solvent & Conv. (\%) & Products & Ref. \\
\hline 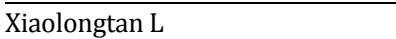 & 400 & 3 & Tetralin & 46 & THFIS, AS, PA, and gas & [16] \\
\hline Xiaolongtan L & 600 & - & Water & 69 & Char yield & [20] \\
\hline Shengli lignite volatiles & $800-1200$ & - & & 70 & Various compounds & [21b] \\
\hline Huolinhe L and longkoal oil shale & 510 & - & Toluene & 72 & Char yield & [92] \\
\hline Xianfeng L thermal extracts & 300 & - & Toluene & 43 & Organic compounds & [93] \\
\hline Shengli L & 330 & - & Benzene and methanol & 42 & HC, ketones, and Phenols & [94] \\
\hline Catalan L & $350-400$ & - & Tetralin and AO & 73 & AS, PA, and oils & [95] \\
\hline Zhaotong L & 305 & - & Ethanol & 65 & Basic N compounds & [96] \\
\hline Spanish L & 500 & 9 & Tetralin & 88 & Oils, AS, and PA & [97] \\
\hline Loy Yang L & 1000 & 3.6 & $\mathrm{H}_{2} \mathrm{SO}_{4}$ & 37 & High pyrolysis products & [98] \\
\hline Yunnan brown coal & 425 & 4 & Tetralin & 80 & Oil yield & [99] \\
\hline Baiyihua L & $500-700$ & 4 & & 31 & Phenols, ketones, etc. & {$[100]$} \\
\hline Mukah Balingian coal & 350 & - & Tetralin Glycerol & 70 & Alkanes, alcohols, etc. & [101] \\
\hline
\end{tabular}

\section{Liquefaction mechanisms and products from lignite}

Lignite coal is macromolecular, having a complex structure with strong intermolecular and intramolecular interactions within the framework. Thus, a high temperature is usually required during the pyrolysis for the cleavage of the strong bonds to produce different products. The bond cleavage gives rise to intermediates, which are converted to more stable products by other chemical reactions. Thus, the direct liquefaction mechanism of lignite coal can be classified into four categories based on the nature of the primary bond cleavage: free radicals, oxidation, carbonium ion formation, and alkanolysis.

Importantly, it can be concluded from Tables 5-7 that the main products formed from the catalytic and non-catalytic liquefaction of lignite coal are PA, AS, and oils. The other products are classified as THF, THFIS, HS, and HIS products. Based on the laboratory supported experimental (LSE) results, we have classified all the organic compounds obtained from lignite coals into various categories, which are discussed in this review.

Furthermore, according to these four different mechanisms, various products will be obtained from different lignite coals. Small aromatic clusters and/or aliphatic chains with some functional groups are formed by a free radical mechanism. Notably, preasphaltene, asphaltene, and oil are distinct products obtained via solvent-fractions from four mechanisms. Oxidative products such as mono-, di-, tri-, and polycarboxylic acids are formed via the oxidation mechanism. Cyclic compounds are produced via hydrogenation through the carbocation formation mechanism. Similarly, esters, ethers, alcohols, and carboxylic acid products are generated via the alkanolysis mechanism.

\subsection{Free radical mechanism}

The free radical mechanism leads to the partial conversion of lignites to small aromatic clusters, with attached to free aliphatic chains; some of the fragments preserve the functional groups derived from those in the original lignite. At high temperatures, free-radical-containing fragments are formed from the lignite molecules, which are unstable and reactive. In the presence of a hydrogen-donor solvent and hydrogen, these reactive fragments stabilize to give the products described above. In particular, the premising action of the catalysts has been described in Section 5.3 above.

\subsubsection{Pyrolysis of the Hulunbeier lignite}

The liquefaction of the Hulunbeier lignite affords a significant tar yield of high quality with the Shendong coal direct liquefaction residue as an additive. Interestingly, the organic compounds present in the direct liquefied residue provide active hydrogen species for the free radicals emitted from lignite pyrolysis, thereby suppressing the amount of poly-condensation reactions. In this way, the quality and tar yield are enhanced after direct liquefaction. The interaction between lignite and the liquefaction residue is important for obtaining a high tar yield. Notably, the pyrolysis of the Hulunbeier lignite with the Shendong coal direct liquefaction residue follows a free radical mechanism [18], as shown in Fig. 3. During the liquefaction, a free radical is formed as an intermediate, which is later converted into tar and THFS (tetrahydrofuran soluble).

\subsubsection{Liquefaction of Shengli lignite coal}

The influence of the reaction temperature was studied in the cornstalk-assisted direct liquefaction of the Shengli lignite coalfield in a resonance agitation micro-autoclave. The effects of cornstalk addition on the product distribution of the lignite liquefaction and on the reaction kinetics have been investigated [76]. The addition of cornstalk significantly improves the reaction kinetics for the liquefaction of the Shengli lignite coal with cornstalk. The products formed include fragments of different molecular weights and polarities, classified as pre-asphaltene, asphaltene, and oil by solvent fractionation. These are the main

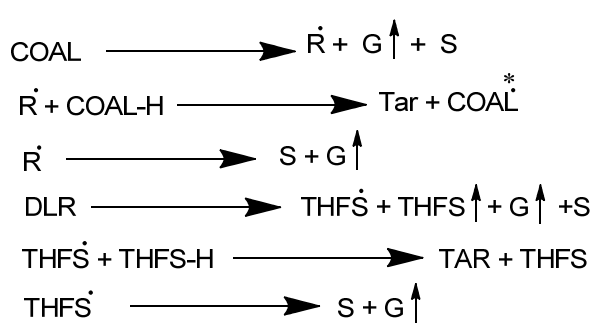

Fig. 3. Formation of tar, THFS, $S$ (solid substance char), coal ${ }^{*}$ (Shendong coal), and G (gas), reproduced from Ref. [18]. 


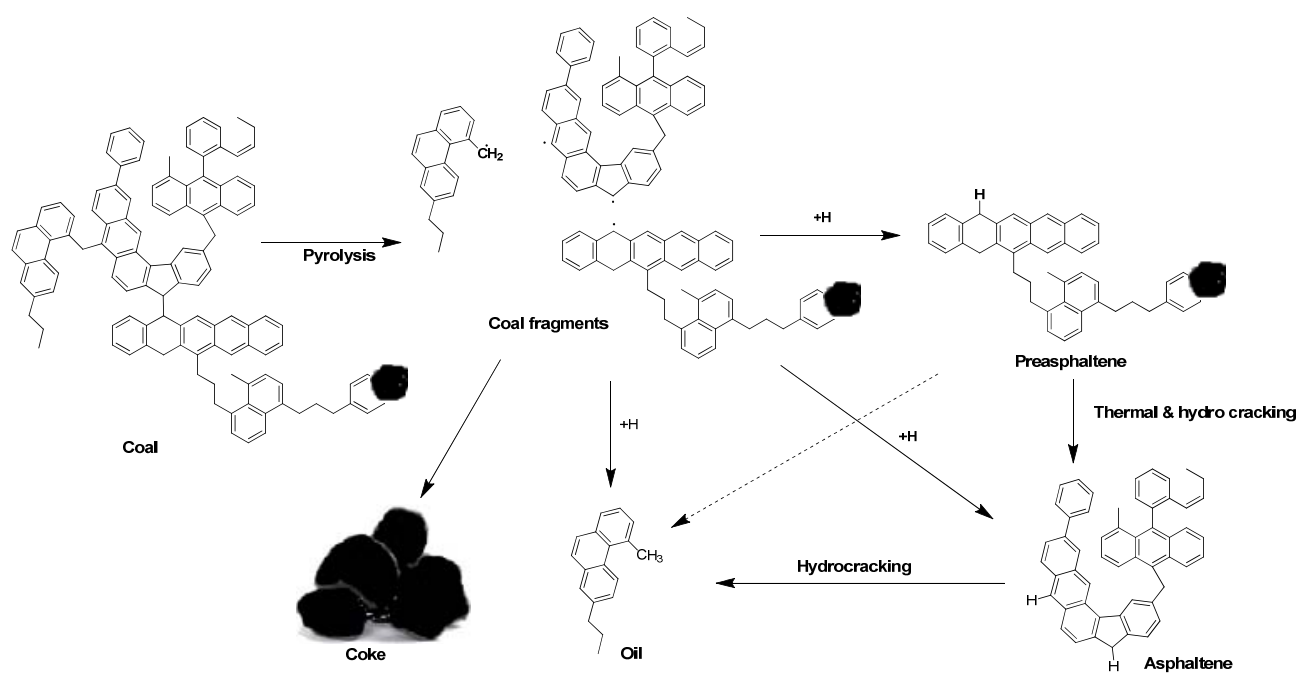

Fig. 4. Typical free radical mechanism scheme for the DCL of diverse lignite coals, reproduced from Ref. [76].

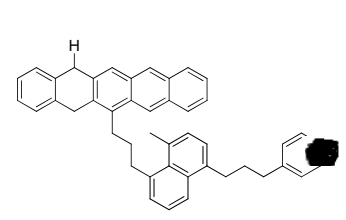

Preasphaltene

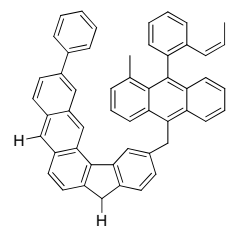

Asphaltene

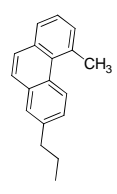

Fig. 5. Molecular representation of PA, AS, and oil, reproduced from Ref. [76].

products obtained from the lignite coal via the free radical mechanism, in which the free radical is formed as an intermediate before the final products in the presence of hydrogen donor solvents. The typical scheme for the free radical mechanism is shown in Fig. 4.

\subsubsection{Preasphaltenes (PA), asphaltenes (AS), and oils, as the main products via a free radical mechanism}

It is believed that the free radical mechanism is important in the liquefaction of many low-ranking coals, such as Xiaolongtan lignite [13], Shengli lignite $[74,75,81]$, Kansk-Achinsk lignite [78], Elbistan lignite [79], Mengen lignite [85], Beypazari lignite [86], Longkou [66], and Catalan lignite [72,95]. The initial free-radical intermediates formed during this mechanism are stabilized to form oil, AS, and PA by catalytic processes involving gaseous hydrogen and a hydrogen donor solvent (Fig. 4). The typical and final products of this mechanism are PA, AS, and oil, as shown in Fig. 5. Since the lignite has a macromolecular structure, the black dots in Figures 4, 5, 6, 8, 12, and 14 rep-

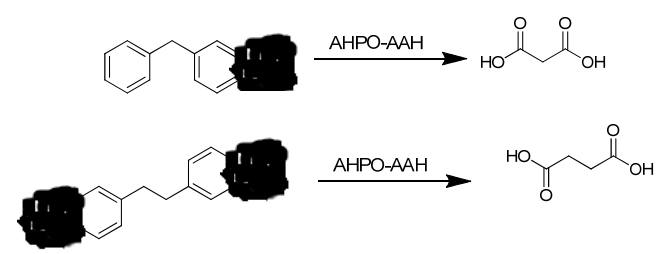

Fig. 6. Formation of malonic acid and succinic acid from XLTL, reproduced from Ref. [84].

resent the macromolecular carbon part of lignite.

\subsection{Oxidation mechanism}

\subsubsection{Oxidation of Xiaolongtan lignite}

The oxidation of the Xiaolongtan lignite (XLTL) was performed in the presence of aqueous hydrogen peroxide-acetic anhydride under optimal conditions [84], as shown in Fig. 6. This process yields a total of forty-seven carboxylic acids. The dominant products observed are aliphatic carboxylic acids, particularly malonic and succinic acids. The cleavage of the carbon-carbon single and double bonds of lignite occurs via an oxidation mechanism. The strong oxidizing agent causes the cleavage of the carbon-carbon double bonds of the aromatic rings in lignite and boosts the oxygen to yield the carboxylic acids. The oxidation products exhibit the structural features of XLTL. Interestingly, XLTL possesses naphthalene carboxylic acid and aliphatic linkages connecting three aromatic rings.

\subsubsection{Oxidation of Loy yang lignite}

The proposed mechanism has been reported for the formation of benzene carboxylic acid [102] from Loy yang lignite coal. The selective chemical degradation was performed using ruthenium tetraoxide, which favored the pyrolytic cleavage of the aromatic group of lignite, which is an oxidation mechanism in the presence of $\mathrm{RuO}_{4}$, as shown in Fig. 7. Here, the cleavage of the aromatic rings of alkylbenzene, 1,3-diphenylpropane,

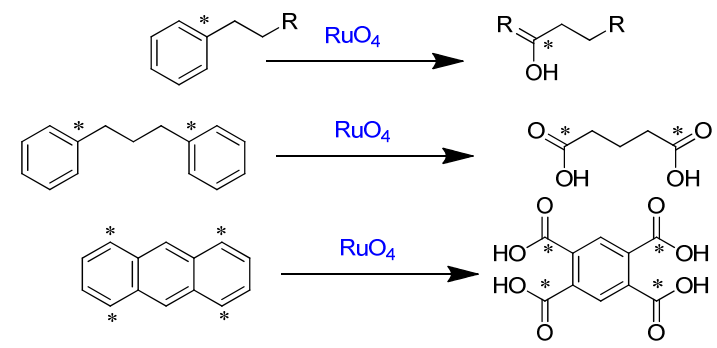

Fig. 7. Formation of oxidative products from lignite coal, reproduced from Ref. [102]. 


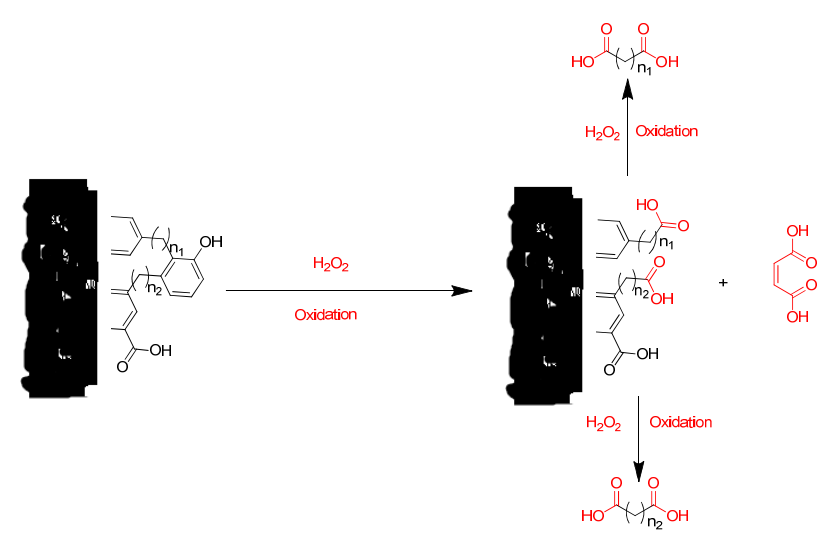

Fig. 8. Oxidative products formed from Xianfeng lignite, reproduced from Ref. [91].

and anthracene occurs in the presence of $\mathrm{RuO}_{4}$ to produce a carboxylic acid. In addition, the possible oxidation mechanism for the formation of benzene carboxylic acids causes the formation of mono-, di-, and tetracarboxylic acids. Notably, straight-chain carboxylic acids have been observed as predominant products $(65 \%-87 \%)$ from the oxidation extracts soluble in dichloromethane.

\subsubsection{Oxidation of Xianfeng lignite (XL)}

A new two-step method was performed to predict and understand the macromolecular network structure of XL. In the first step, thermal extracts (TE) were achieved at $320^{\circ} \mathrm{C}$, and in the second step, the residue formed was oxidized using $5 \%$ $\mathrm{H}_{2} \mathrm{O}_{2}$ aqueous solution. A possible mechanism for the oxidation of Xianfeng lignite has been presented [91]. It is an oxidation mechanism (Fig. 8), which occurs in the presence of hydrogen peroxide as an oxidizing agent. Similarly, the oxidative mechanism of Xianfeng lignite involves the cleavage of aromatic rings and proceeds by inserting oxygen atoms to yield the carboxylic acids. The cleavage usually involves the breakdown of double-bonded carbons into their respective carboxylic acids.

\subsubsection{Oxidative products via oxidation mechanism}

Generally, the oxidative products of lignite coal (carboxylic acids) thus produced, can be classified into mono-, di-, tri-, tetra-, and polycarboxylic acids, as shown in Fig. 9. The dicarboxylic acid products are more dominant than other carboxylic acid products. Further investigation reveals that the major products among the di-carboxylic acids are malonic and succinic acids. Indeed, the oxidized products obtained from various lignites such as Xiaolongtan lignite [84], Xianfeng lignite [91], Loy yang lignite [102], and Huolinguole lignite [104] are carboxylic acids. During the oxidation, oxygen attaches to the double-bonded carbons of aromatic rings, thereby producing the respective carboxylic acids under drastic conditions. More importantly, the absence of sulfur, nitrogen, and minerals in the oxidative products reveal that desulfurization, denitrogenation, and demineralization are dominant processes that occurred during their formation. The strong oxidizing agents cause the cleavage of the aromatic rings of diverse lignite coals and generate the respective carboxylic acids. Therefore, it can also be corroborated that the formation of carboxylic acids from diverse lignite coals demonstrates the complete oxidation of the lignite coals.

\subsection{Hydrogenation mechanism via carbocation formation}

\subsubsection{Cleavage of Car-Calk bond via carbocation formation}

Aromatic compounds (Fig. 11) (naphthalene and other bicyclic compounds) are formed from lignite coals. Here, di(1-naphthyl)methane (DNM) was used as a coal-related model compound to investigate the cleavage of C-alkyl and $\mathrm{C}$-aromatic bonds as evidence of the same cleavage in lignite coals. The new solid acid catalyst (NSA) synthesized via the

6.2.4.1. Monocarboxyic acids

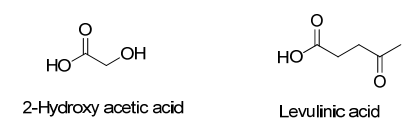<smiles>O=C(O)c1ccccc1</smiles>

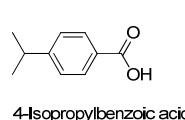<smiles>O=C(O)CCC(=O)O</smiles>

6.2.4.2. Dicarboxylic acids

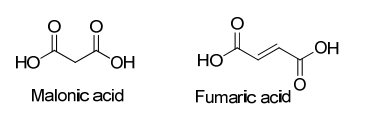<smiles>O=C(O)CCCCC(=O)O</smiles>
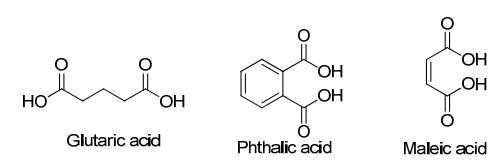

6.2.4.3. Tricarboxylic acids
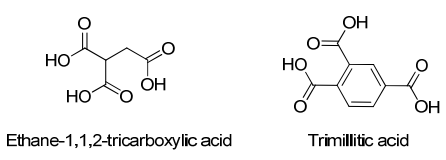

6.2.4.4. Tetracarboxylic acids
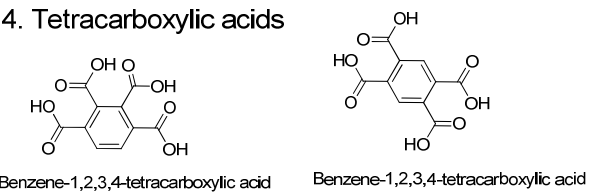

Fig. 9. Mono-, di-, tri-, and tetracarboxylic acids from diverse lignite coals, reproduced from Refs. [84,91,102,104]. 


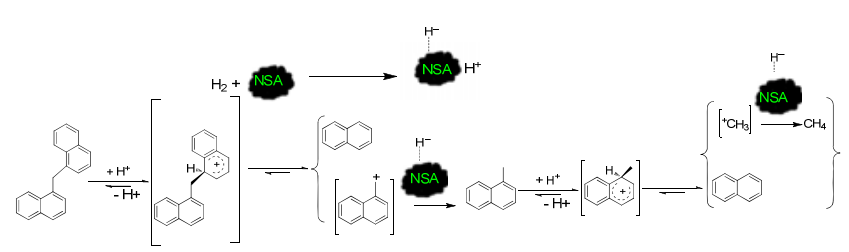

Fig. 10. Mechanism of the hydrogenation via carbocation formation, reproduced from Ref. [103].

impregnation method using isometric PCA (penta-chloro-antimony) and TMSTFMS (trimethyl-silyl-tri-fluoro-methane-sulfonate) on AC (activated carbon) was applied in the degradation process. The cleavage of the $\mathrm{C}_{a r}-\mathrm{C}_{\text {alk }}$ bonds occurs via a carbocation formation [103] (Fig. 10). This phenomenon occurs under mild conditions through the hydrogen transfer process in the presence of pressurized hydrogen. The coal-related model compound undergoes a possible hydrogenation mechanism, whereas the NSA catalyst favors the ionization (splitting) of hydrogen into $\mathrm{H}^{+}$and $\mathrm{H}^{-}$[105]. Afterward, $\mathrm{H}^{+}$generates the arenium ion or benzonium ring in the aromatic part of lignite via protonation. The benzonium or arenium ion is highly unstable, and it produces carbocation or carbonium ion. Meanwhile, the formed carbocation converts into the respective product. Therefore, via this mechanism, 1-methyl naphthalene could be transformed into naphthalene.

\subsubsection{Cyclic products via carbonium formation mechanism}

A study on the different lignite coals including Shengli lignite [15,20,83], Elbistan lignite [79], and Mulah low-ranking coal [101] has been carried out under different conditions. The cyclic products obtained via direct liquefaction can be categorized into mono-, bi-, tri-, and polycylic (Fig. 11). The bicyclic

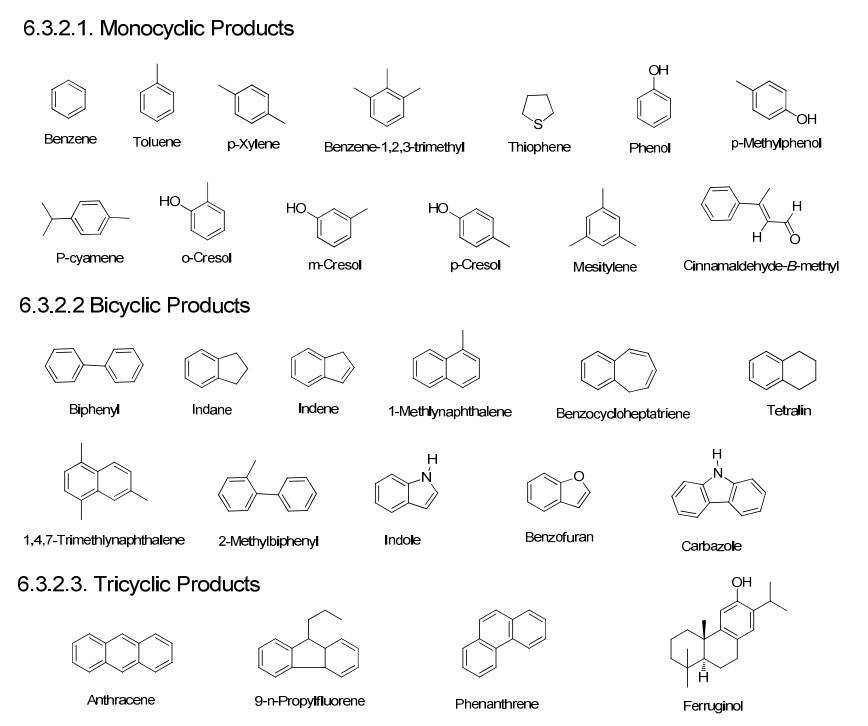

6.3.2.4. Polycyclic compounds
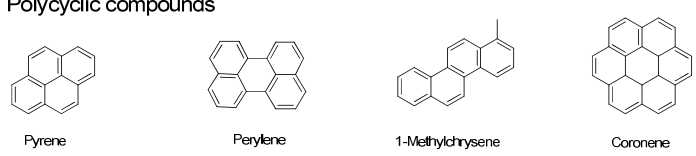

Fig. 11. Mono-, di-, tri-, and polycyclic compounds from diverse lignites, reproduced from Refs. [15,20,79,38,101.103]. products are formed by the cleavage of carbon-carbon bonds via the carbocation [103] formation mechanism.

The hydrogenation mechanism through the formation of carbocation occurs in the presence of a catalyst and hydrogen. In fact, the catalyst is essential for the ionization of hydrogen to a proton $\left(\mathrm{H}^{+}\right)$and $\left(\mathrm{H}^{-}\right)$. Afterward, the proton causes the formation of arenium or benzonium ion in the case of benzene. The arenium or benzonium ion is highly unstable, and it converts into carbonium ion or carbocation. The carbocation, formed as an intermediate, generates the respective mono-, bi-, and polycyclic compounds (Fig. 11).

\subsection{Alkanolysis mechanism}

Further study on the mechanism of the diverse lignite coal reveals that the Huolinguole lignite (HL) undergoes degradation via an alkanolysis mechanism to produce various products [104]. The dissociation of the inter-molecular interactions occurs at temperatures lower than 240 and $270{ }^{\circ} \mathrm{C}$ in the presence of methanol and ethanol, respectively. In addition, the alkanolysis mechanism favors the conversion of large lignite coal fragments of ether and ester functions into relatively small molecules of ether, ester, alcohol, and carboxylic acids. The esteric group of lignite undergoes hydrolysis to generate carboxylic acids. Therefore, it can be said that alkanolysis is one of the important bond cleavage processes for obtaining useful products. Thus, the thermal degradation of HL causes the cleavage of intermolecular interactions in the presence of methanol and ethanol solvents at low temperatures in $\mathrm{N}_{2}$. Notably, various possible routes are involved in the alkanolysis mechanism, which favor the formation of alcohols, ethers, esters, and other products.

\subsubsection{Formation of alcohol and ether}

The aromatic ethers of diverse lignite coal undergo alkanolysis cleavage to yield relatively small aromatic ethers, small aliphatic ethers, aromatic alcohols, and aliphatic alcohols. This conversion usually occurs in the presence of methanol or ethanol solvent at certain temperatures (Fig. 12). In addition, aromatic esters, via the alkanolysis mechanism, generate aromatic ethers, aliphatic acids, aliphatic esters, alkanes, aromatic alcohols, small aromatic esters, and aliphatic acids (Fig. 13). Conversely, aromatic esters yield small aromatic esters, aliphatic alcohols, aromatic compounds, aromatic carboxylic ac-

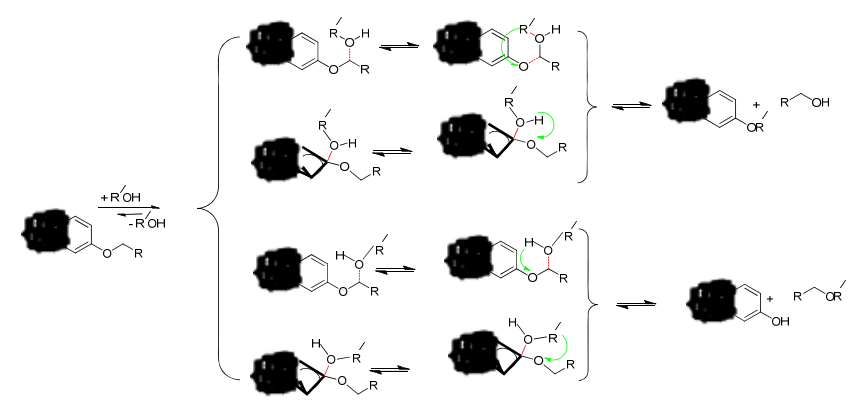

Fig. 12. Possible pathway for the formation of alcohols and ethers from lignite, reproduced from Ref. [104]. 


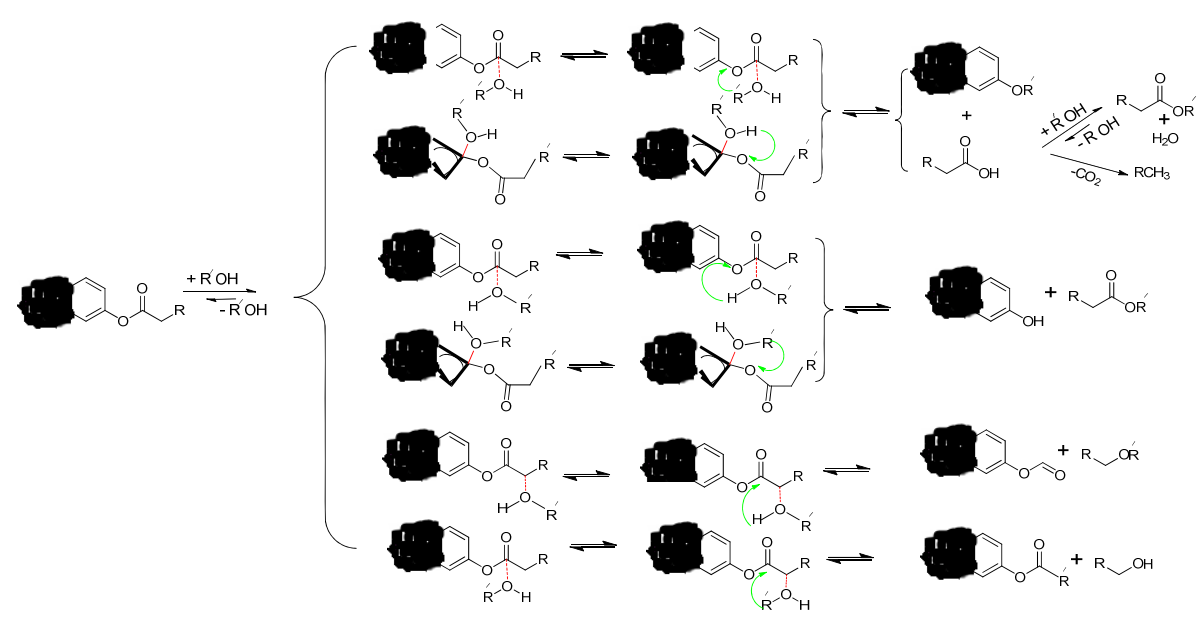

Fig. 13. Possible pathways for the formation of alcohol, ether, ester, and other products, reproduced from Ref. [104].

ids, aromatic alcohols, and aliphatic esters (Fig. 14). Similarly, R represents an alkyl or an aryl group, whereas Ŕ represents a methyl or an ethyl group in the above possible pathways of alkanolysis.

\subsubsection{Formation of alcohol, ether, ester, and other products}

\subsubsection{Formation of ester, alcohol aromatic acids, and other} aromatic compounds

Consequently, various liquid products can be detected after the direct liquefaction of lignite coals from Shengli lignite, $[15,83]$ Xianfeng lignite, [91,83], and Huolinguole lignite [104]. As has been shown in Fig. 15, the liquefied products are categorized into aliphatic hydrocarbons, alcohols, ethers, ketones, and esters based on their functional groups. Aliphatic hydrocarbons are the cracked products formed during alkanolysis via decarboxylation (Fig. 13). However, the appearance of various products does not necessarily involve alkanolysis. The oxygen-containing products including alcohols, ethers, esters, and other carboxylic acids are formed by the alkanolysis mechanism shown in Figs. 12-14.

In fact, the presence of long aliphatic chains is established by the solid-state ${ }^{13} \mathrm{C}$ NMR analysis of the coals and ${ }^{1} \mathrm{H}$ NMR analysis of the products. Similarly, the carboxylic acids and alcoholic products are produced by the hydrolysis process. Disparate ester compounds are formed by the esterification of lignite in the presence of methanol or ethanol. Thus, large aromatic esters and ethers degrade into relatively small aromatic esters or ethers, aliphatic ethers, aromatic alcohols, aliphatic alcohols, and carboxylic acids via the alkanolysis mechanism [104].

\section{Conclusions and outlook}

Direct liquefaction can generate various products from low-ranking lignite via hydrocracking, oxidative cleavage, and alkanolysis reactions. In catalytic hydrocracking, iron-based catalysts have been shown to be quite effective attributed to their ability to minimizing the activation energies, while tetra-

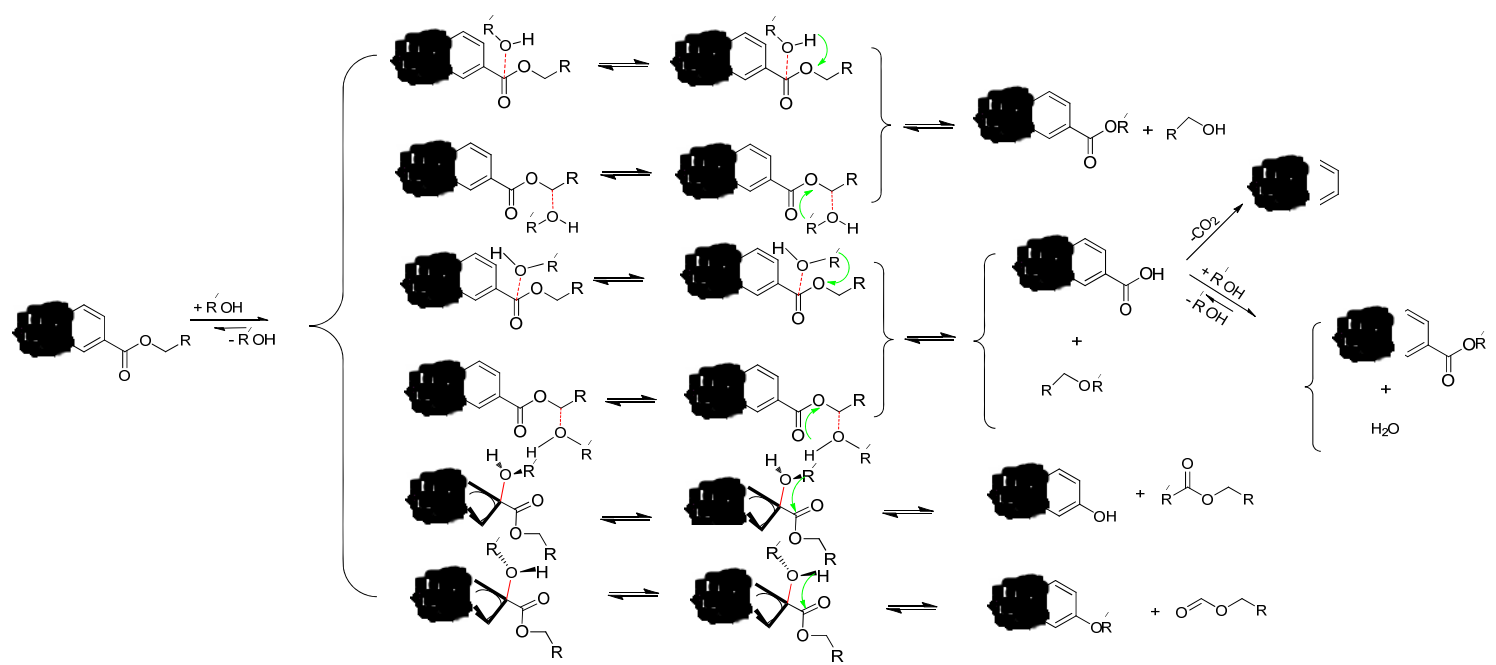

Fig. 14. Possible pathways for the formation of esters, alcohols, and aromatic compounds, reproduced from Ref. [104]. 


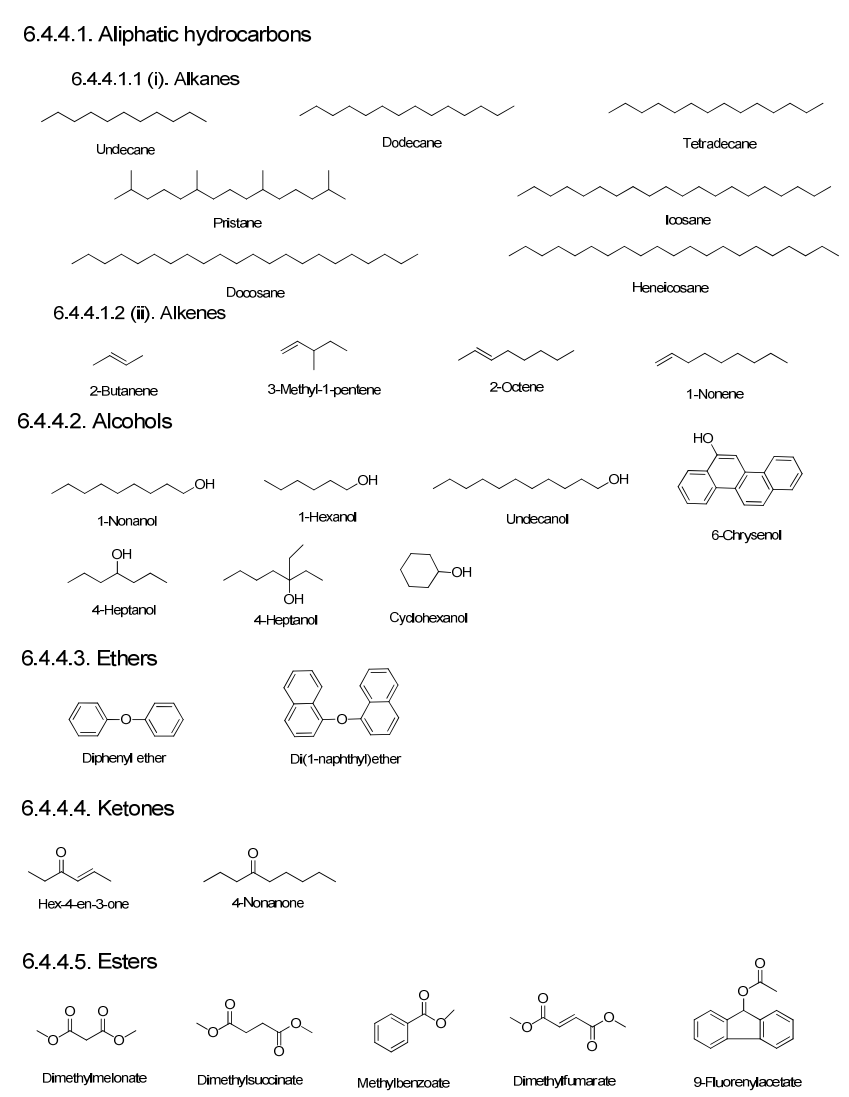

Fig. 15. Aliphatic hydrocarbons, alcohols, ethers, and ketones from diverse lignite coals, reproduced from Ref. [104].

lin acts as the proper hydrogen donor solvent for laboratory-supported experiments. In addition, the Shenhua II technology using a suspended bed reactor and iron-based catalyst possess a high capacity for lignite coal liquefaction. Furthermore, various useful products have been detected during the direct liquefaction process from lignite coals by degradation, hydrolyzation, desulfurization, denitrogenation, demineralization, and hydrogenation. The liquefied products can be arranged into disparate groups, such as aromatic-ring products (preasphaltene, asphaltene, and oil), oxidative products, cyclic products, and alkanolysis products with hydrocarbons, based on the mechanism of the liquefaction. Depending on the functional groups, gas atmosphere, solvent, and type of cleavage in lignite, the prevailing mechanisms are involved during the liquefaction via oxidation, free radical formation, carbocation formation, and alkanolysis; however, the cracking of lignite generally follows the free radical mechanism in the presence of hydrogen and a catalyst. In addition, the oxidation mechanism generally yields more oxidative products, such as carboxylic acids. Similarly, a high energy input is required to cleave the carbon-carbon double bond; thus, the cleavage in lignite occurs under drastic conditions. It can be concluded from the observed data that monocyclic compounds are the dominant products, including phenol, toluene, and p-cymene, among the cyclic products. This review on the liquefaction of low-ranking lignite coal may motivate researchers to develop more efficient catalytic systems for the liquefaction of lignite (low-ranking coal) in the future.
In fact, a variety of products has been produced using various synthetic strategies via direct liquefaction techniques to elevate the value of lignite coal. Moreover, indirect liquefaction can be applied to achieve liquid-fuels. An excellent review by Larson et al. [37] on indirect coal liquefaction (ICL), explains, in detail, the catalytic conversion of syn-gas to clean hydrocarbons and oxygenated transportation fuels. The recent review [30] on ICL addresses the gasification of lignite coal at about $1000{ }^{\circ} \mathrm{C}$ to obtain useful gases for power generation (Fig. 1). This process operates at a high temperature with a significant loss of chemical energy. Conversely, a DCL process such as IGOR operates at a temperature range of $290-330{ }^{\circ} \mathrm{C}$ [61] in a fixed bed reactor with a capacity of $200 \mathrm{t} / \mathrm{d}$, whereas the Shenhua DCL is an efficient process, which affords $90 \%-92 \%$ coal conversion in a suspended bed reactor using 5\%-7\% hydrogen. Therefore, the implementation of DCL on an industrial scale is expected in the future.

In this review, we discussed the NEDOL technology in detail. The main distinguishing characteristic of the NEDOL process is the downstream solvent hydrogenation section (Fig. 2) because oil \#3 in recycled oil plays a key role in sustaining the hydrogen donor capability of the recycled oil. The recycled solvent is a mixture of more than 200 compounds, including paraffin, naphthenes, indenes, pyrenes, and aromatics [62]. Nevertheless, some aromatic compounds (biphenyls) are cracked during hydrothermal treatment at $455^{\circ} \mathrm{C}$, due to the decrease in their ring number. To solve this issue, the aromatic compounds containing a naphthenic ring in naphthalene, phenanthrene, or anthracene as a hydrogen donor solvent should be used to promote the liquefaction. Similarly, we provided an overview of the pilot-plant stages of the Shenhua project, in detail, and discussed very little on the full-scale plant. We suggest Ref. [69] for more information on the Shenhua full-scale plant. Furthermore, the Xianfeng lignite exhibited a high efficient conversion (97.5\%) and afforded the least residues during liquefaction by IGOR, as shown in Table 3. However, some operating data for the same HTI, FFI, NEDOL, or Shenhua processes are not available from the published literature. Therefore, future studies are expected to process lignite coal by HTI, FFI, NEDOL, and Shenhua processes over iron-based catalysts for highly efficient conversion. In addition, detailed descriptions of the FFI, HTI, and IGOR full-scale plants are the main future research focus, which cannot be obtained from open literature.

This review covers the state-of-the-art fabrication of various products from different kinds of lignite coals, with effective iron-based catalysts showing promise. The correlation between the formed products and the type of cleavages was elucidated in detail. Furthermore, the typical mechanisms are described in this review. However, the mechanism for the co-liquefaction of lignite coal and biomass (other additives) has not been fully elucidated; therefore, further study is required. Our contribution provides an outline for researchers to obtain useful products from low-ranking lignite coal. The well-defined products formed via solvent-fraction during liquefaction contain relatively high yields of HS, HIS, THF, and THFI products. However, achieving high yields and selectivity of individual targeted aromatic compounds and hydrocarbons (benzene, phenol, lighter 


\section{Graphical Abstract}

Chin. J. Catal., 2020, 41:375-389 doi: S1872-2067(19)63492-3

Direct liquefaction techniques on lignite coal: A review

Arif Ali, Chen Zhao *

East China Normal University

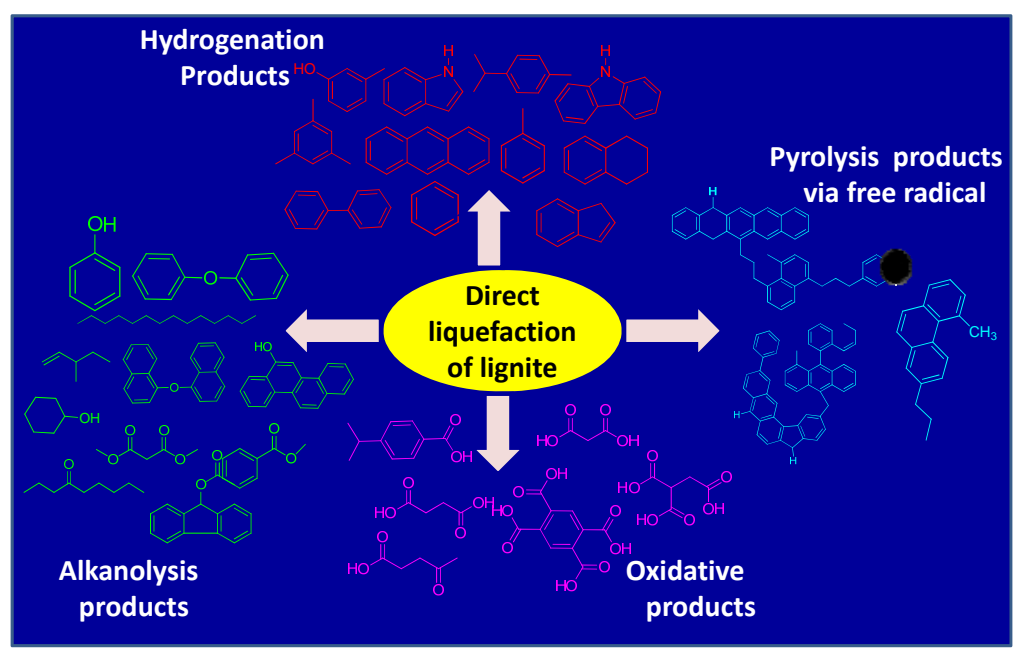

This review focuses on liquefaction techniques and the state-of-the-art fabrication of various products from a variety of lignites via the direct liquefaction process. Based on the nature of primary bond cleavages in the direct liquefaction mechanism, the products were arranged as pyrolysis, oxidative, hydrogenation, and alkanolysis products.

acids, paraffin, etc.), as obtained for the main products, is a significant challenge to be addressed by future investigations. Although iron-based catalysts exhibit great promise for hydrogenation via hydrocracking during direct liquefaction, the origin of the improved activity and selectivity remains a topic for debate. In summary, all the issues outlined can be gradually solved with joint global efforts based upon a mechanistic understanding of the fundamental aspects.

\section{References}

[1] C. Zhao, T. Brück, J. A. Lercher, Green Chem., 2013, 15, 1720-1739.

[2] W. Li, L. Sun, L. Xie, X. Deng, N. Guan, L. Li, Chin. J. Catal., 2019, 40, 1255-1281.

[3] A. Ali, B. Li, Y. Lu, C. Zhao, Green Chem., 2019, 21, 3059-3064.

[4] C. Zhao, Y. Kou, A. A. Lemoniduo, X. Li, J. A. Lercher, Angew. Chem., Int. Ed., 2009, 48, 87-3990.

[5] J. Kong, M. He, J. A. Lercher, C. Zhao, Chem. Commun., 2015, 51, 80-17583.

[6] Z. Zheng, Z. Luo, C. Zhao, ChemCatChem, 2018, 10, 1376-1384.

[7] Z. Luo, Z. Zheng, Y. Wang, G. Sun, H. Jiang, C. Zhao, Green Chem., 2016, 18, 5845-5858.

[8] B. Ma, X. Yi, L. Chen, A. Zheng, C. Zhao, J. Mater. Chem. A, 2016, 4, 11330-11341.

[9] (a) J. Zhang, C. Zhao, ACS Catal., 2016, 6, 4512-4525, (b) B. Peng, Y. Yao, C. Zhao, A. Lercher, Angew. Chem., Int. Ed., 2012, 51, 2072-2075.

[10] Z. Luo, C. Zhao, Catal. Sci. Technol., 2016, 6, 3476-3484.

[11] L. Wu, L. Li, B. Li, C. Zhao, Chem. Commun., 2017, 53, 6152-6155.
[12] Z. Jingjing, C. Zhao, Chem. Commun., 2015, 51, 17249-17252.

[13] Z. Wang , J. Hu, H. Shui, S. Ren, C. Wei, C. Pan, Z. Lei, X. Cui, Fuel, 2013, 109, 94-100.

[14] X. Li, D. E. Priyanto, R. Ashida, K. Miura, Energy Fuels, 2015, 29, 3127-3133.

[15] L. C. Yu, X. Y. Wei, Y. H. Wang, D. D. Zhang, Z. M. Wen, Z. Zong, X. Fan, Y. P. Zhao, W. Zhao, Y. L. Zhu, Fuel Process. Technol., 2014, 126, 131-137.

[16] B. Wang, Y. Huang, J. Zhang, J. Anal. Appl. Pyrol., 2014, 110, 382-389.

[17] X. Li, Z. Q. Bai, J. Bai, B. B. Zhao, P. Li, Y. N. Han, L. X. Kong, W. Li, Fuel Process. Technol., 2015, 133, 161-166.

[18] X. Li, Y. Xue, J. Feng, Q. Yi, W. Li, X. Guo, K. Liu, Fuel, 2015, 144, 342-348.

[19] J. Li, J. Yang, Z. Liu, Fuel Process. Technol., 2009, 90, 490-495.

[20] P. Liu, L. Wang, Y. Zhou, T. Pan, X. Lu, D. Zhang, Fuel, 2016, 164, 110-118.

[21] (a) Z. Wang, H. Shui, Z. Pei, J. Gao, Fuel, 2008, 87, 527-533, (b) Q. He, K. Wan, A. Hoadley, H. Yeasmin, Z. Miao, Fuel, 2015, 156, 121-128.

[22] M. S. A. Perera, P. G. Ranjith, S. K. Choli, A. Bouazza, J. Kodikara, D. Airey, Environ. Earth Sci., 2011, 64, 223-235.

[23] Y. Jianglong, T. Arash, H. Yanna, Y. Fengkui, L. Xianchun, Fuel Process. Technol., 2013, 105, 9-20.

[24] R. C. Milici, Nat. Res. Res., 2009, 18, 85-94.

[25] M. Widera, Act. Geo. Polon., 2015, 65, 367-378.

[26] C. Zhang, X. He, S. Zhu, X. Wang, H. Zhuang, Comp. Society, 2011, 8, $1-4$.

[27] J. Hyashi, S. Kudo, H. S. Kim, K. Norinaga, K. Matsuoka, S. Hosokai, Energy Fuels, 2014, 28, 4-21. 
[28] P. Samuel, S. Maity, S. Khan, S. C. Roy, J. Sci. Ind. Res., 2008, 67, 1051-1058.

[29] M. V. Kok, M. R. Pamir, Ana. Appl. Pyrolysis, 1995, 35, 145-156.

[30] N. Nikolopoulos, I. Violidakis, E. Karampinis, M. Agraniotis, C. Bergins, P. Grammelis, E. Kakaras, Fuel, 2015 155, 86-114.

[31] P. J. Ashman, P. J. Mullinger, Fuel, 2005, 84, 1195-1205.

[32] C. Z. Li, Fuel, 2007, 86, 1664-1683.

[33] J. P. Mathews, A. L. Chaffee, Fuel, 2012, 96, 1-14.

[34] B. Bielowics, J. R. Kasinski, Inter. J. Coal Geology, 2014, 131, 304-318.

[35] N. Wijaya, L. Zhang, Energy Fuels, 2011, 25, 1-16.

[36] H. Shui, Z. Cai, C. Xu, Energy Fuels, 2010, 3, 155-170.

[37] E. Larson, T. Ren, Energy Sus. Develop., 2003, 7, 79-102.

[38] N. Mallya, R. Zingaro, ACS symposium series, Oxford University Press., 1984, 133-144.

[39] P. G. Hatcher, J. L. Faulon, K. A. Wenzel, G. D. Cody, Abstracts of papers of Am Chem Soc 1155 16TH ST, NW, Washington, DC 20036, 1992, 203, 93.

[40] P. Tromp, J. Moulijn, Coal Sci. Springer, 1988, 305-338.

[41] E. A. Wolfrum, Abstracts of Am. Chem. Soc., Washington, DC. 1983, $186,44$.

[42] T. Vu, I. Yarovsky, A. Chaffee, 12th international conference on coal science and technology, 2005, 9-14.

[43] G. Domazetis, B. D. James, Org. Geochem., 2006, 37, 244-259.

[44] H. Kumagai, J. Hayashi, T. Chiba, K. Nakamura, Abstracts of Papers of Am. Chem. Soc., Washington, DC. 1999, 44, 633-637.

[45] K. J. Hüttinger, A. W. Michenfelder, Fuel, 1987, 66, 1164-1165.

[46] K. Iwata, H. Itoh, K. Ouchi, T. Yoshida, Fuel Process. Technol., 1980, 3, 221-229.

[47] Y. F. Patrakov, V. F. Kamyanov, O. N. Fedyaeva, Fuel, 2005, 84, 189-199.

[48] D. VanKrevelen, J. Schuyer, Amsterdam: Elsevier, 1957, 2852-2863

[49] J. H. Shinn, Fuel, 1984, 63, 87-96.

[50] C. V. Philip, R. G. Anthony, ACS Symposium Series, 1984, 245, 257-270.

[51] I. Wender, Catal. Rev. Sci. Eng., 1976, 14, 97-129.

[52] P. R. Solomon, M. A. Serio, G. V. Despande, E. Kroo, Energy Fuels, 1990, 4, 42-54.

[53] (a) F. Derbyshire, A. Davis, M. Epstein, P. Stansberry, Fuel, 1986, 65, 1233-1239, (b) F. Derbyshire, P. Stansberry, Fuel, 1987, 66, 1741-1742.

[54] L. Huang, H. H. Schobert, Energy Fuels, 2005, 19, 200-207.

[55] M. Godo, M. Saito, A. Ishihara, T. Kabe, Fuel, 1998, 77, 947-952.

[56] Z. Wang, H. Shui, Z. Pei, J. Gao, Fuel, 2008, 87, 527-533.

[57] K. Shimizu, H. Kawashima, Energy Fuels, 1999, 13, 1223-1229.

[58] F. V. Stohl, H. P. Stephens, Ind. Eng. Chem. Res., 1987, 26, 2466-2473.

[59] M. Polubentseva, V. Duganova, B. Bazhenov, G. Mikhailenko, Sol. Fuel. Chem., 1997, 31, 65-73.

[60] Y.Shah, NASA STI Tech Report A 1981.

[61] M. Onozaki, Y. Namiki, H. Ishibashi, M. Kobayashi, H. Itoh, M. Hiraide, S. Morooka, Fuel Process. Technol., 2000, 64, 253-269.

[62] M. Kouzu, K. Koyama, M. Oneyama, T. Aramaki, T. Hayashi, M. Kobayashi, H. Itoh, H. Hattori, Fuel, 2000, 79, 365-371.

[63] A. Irwin, H. Cochkran, O. Culberson, J. Fisher, W. Gambill, G. Oswald, R. Salmon, Oak Ridge National Laboratory (USA), ORNL/TM-9181, 1985.

[64] C. Irwin, A. Sincali, E. Wong, Oak Ridge National Laboratory (USA). ORNL/MIT-326, 1981.

[65] (a) C. Tsonopoulos, J. Heideman, S. Hwang, An Exxon Monograph, Wiley, New York, 1986, (b) J. A. Gray, C. J. Brady, J. R. Cunningham,
J. R. Freeman, G. M. Wilson, Ind. Eng. Chem. Process. Des. Dev., 22 1983, 24, 97-107.

[66] J. Cai, Y. Wang, Q. Huang, Fuel, 2008, 87, 3388-3392.

[67] C. Song, H. Schobert, P. G. Hatcher, Energy Fuels, 1992, 6, 326-328.

[68] L. Huang, H. H. Schobert, Energy Fuels, 2005, 19, 200-207.

[69] A. G. Comolli, T. L. K. Lee, G. A. Popper, P. Zhou, Fuel Process. Technol., 1999, 59, 207-215.

[70] L. Zhao, K. S. Gallagher, Energy Policy, 2007, 35, 6467-6477.

[71] D. L. Cillo, G. J. Stiegel, R. E. Tischer, N. K. Narain, Fuel Process. Technol., 1985, 11, 273-287.

[72] C. Bengoa, J. Font, A. Moros, A. Fortuny, A. Fabregat, F. Giralt, Fuel, 1996, 75, 1327-1330.

[73] H. Karaca, K. Ceylan, Fuel, 2002, 81, 1767-1771.

[74] L. Li, S. Huang, S. Y. Wu, Y. Q. Wu, J. S. Gao, Fuel Process. Technol., 2015, 138, 109-115.

[75] Z. Lei, M. Liu, L. Gao, H. Shui, Z. Wang, S. Ren, Energy, 2011, 36, 3058-3062.

[76] F. Zhang, D. Xu, Y. Wang, X. Guo, L. Xu, M. Fan, Appl. Energy, 2014, 130, 1-6.

[77] Y. Xu, X. Sun, R. Song, D. Zhang, J. Gao, Energy Sources A, 2012, 34, 1695-1703.

[78] P. N. Kuznetsov, V. I. Sharypov, M. G. Kurochkin, T. M. Pospelova, E. D. Kornietz, V. A. Trukhacheva, V. G. Chumakov, React. Kinet. Catal. Lett., 1989, 38, 255-260.

[79] H. Karaca, C. Koyunoğlu, Energy Sources A, 2010, 32, 1167-1175.

[80] Z. Lei, M. Liu, H. Shui, Z. Wang, X. Wei, Fuel Process. Technol., 2010, 91, 783-788.

[81] H. Shui, W. Zhu, W. Wang, C. Pan, Z. Wang, Z. Lei, S. Ren, S. Kang, Fuel, 2015, 139, 516-522.

[82] Z. Lei, Z. Hu, H. Zhang, L. Han, H. Shui, S. Ren, Z. Wang, S. Kang, C. Pan, Fuel, 2016, 166, 124-129.

[83] Y. B. Wei, X. Y. Wei, L. C. Yu, P. Li, Z. M. Zong, W. Zhao, Energy Sources A, 2013, 35, 2302-2309.

[84] J. Liu, X. Y. Wei, Y. G. Wang, D. D. Zhang, T. M. Wang, J. H. Lv, J. Gui, M. Qu, Z. M. Zong, Fuel, 2015, 142, 268-273.

[85] G. Gürüz, N. Baç, H. Orbey, E. Inanç, M. S. Erdem, Fuel Sci. Technol. Int., 1991, 9, 1071-1085.

[86] Y. Yürüm, J. Özkisacik, S. Bektaş, Petrol. Sci. Technol., 1990, 8, 1005-1019.

[87] K. Y. Shi, X. X. Tao, S. D. Yin, Y. Du, Z. P. Lv, Proc. Earth Planet Sci., 2009, 1, 627-633.

[88] M. Trautmann, S. Lang, Y. Traa, Fuel, 2015, 151, 102-109.

[89] M. Stefanova, L. Gonsalvesh, S. Marinov, J. Czech, R. Carleer, J. Yperman, Fuel, 2016, 165, 324-330.

[90] M. T. Erol, A. Olcay, Fuel Sci. Technol. Int., 1994, 12, 433-442.

[91] C. X. Pan, X. Y. Wei, H. F. Shui, Z. C. Wang, J. Gao, C. Wei, X. Z. Cao, Z. M. Zong, Fuel, 2013, 109, 49-53.

[92] D. He, J. Guan, H. Hu, Q. Zhang, Oil Shale, 2015, 32, 151-156.

[93] Z. Wang, H. Shui, C. Pan, L. Li, S. Ren, Z. Lei, S. Kang, C. Wei, J. Hu, Fuel Process. Technol., 2014, 120, 8-15.

[94] M. Ding, Y. P. Zhao, Y. Q. Dou, X. Y. Wei, X. Fan, J. P. Cao, Y. L. Wang, Z. M. Zong, Fuel Process. Technol., 2015, 135, 20-24.

[95] J. Giralt, A. Fabregat, F. Giralt, Ind. Eng. Chem. Res., 1988, 27, 1110-1114.

[96] Z. K. Li, Z. M. Zong, H. L.Yan, Z. H. Wei, Y. Li, X. Y. Wei, Fuel, 2015, 141, 268-274.

[97] I. De-Marco, M. J. Chomón, J. A. Legarreta, A. Torres, Fuel Sci. Technol. Int., 1991, 9, 1123-1135.

[98] C. Sathe, J. Hayashi, C. Z. Li, T. Chiba, Fuel, 2003, 82, 343-350.

[99] J. Yan, Z. Bai, W. Li, J. Bai, Fuel, 2014, 136:280-286.

[100] X. B. Feng, J. P. Cao, X. Y. Zhao, C. Song, T. L. Liu, J. X. Wang, X. Fan, X. Y. Wei, J. Anal. Appl. Pyrol., 2016, 117, 106-115. 
[101] S. N. Ali, M. F. Yusop, K. Ismail, Z. A. Ghani, M. F. Abdullah, M. A. M. Ishak, A. R. Mohamed, Energy Procedia, 2014, 52, 618-625.

[102] R. J. Boucher, G. Standen, G. Eglinton, Fuel, 1991, 70, 695-702.

[103] X. M. Yue, X. Y. Wei, B. Sun, Y. H. Wang, Z. M. Zong, X. Fan, Z. W. Liu, J. Appl. Catal. A, 2012, 425, 79-84.
[104] H. Y. Lu, X. Y. Wei, R. Yu, Y. L. Peng, X. Z. Qi, L. M. Qie, Q. Wei, J. Lv, Z. M. Zong, W. Zhao, Y. P. Zhao, Z. H. Ni, L. Wu, Energy Fuels, 2011, 25, 2741-2745.

[105] Z. P. Hu, D. Yang, Z. Wang, Z. Y. Yuan, Chin. J. Catal., 2019, 40, 1233-1254.

\title{
褐煤直接液化技术研究进展 \\ 林 凯 ${ }^{\mathrm{a}}$, 赵晨 ${ }^{\mathrm{a}, \mathrm{b}, *}$ \\ a 华东师范大学化学与分子工程学院, 上海市绿色化学与化工过程绿色化重点实验室, 上海200062 \\ b华东师范大学崇明生态研究院, 上海200062
}

\begin{abstract}
摘要: 褐煤是一个具有复杂结构的低等级煤炭, 具有高水分、低发热值和低灰量. 此外, 褐煤是含有多种杂质的多孔材料, 低分子量的有机化合物之间通过氢键结合. 各种形式的褐煤含有水分灰硫、硫酸盐硫、黄铁矿硫和挥发物等杂质, 现存在 多种预处理方法, 如 $10 \%$ 盐酸预处理, $\mathrm{HCl}-\mathrm{HF}$ 预处理, 氧化预处理、溶剂肿胀、溶剂萃取、微波处理、硝酸氧化、微生物脱 硫等.

褐煤直接液化可以通过加氢裂化, 氧化裂解和烷醇分解反应从低级褐煤中产生各种产物. 在催化加氢裂化中, 铁基催 化剂表现出最小活化且非常高效, 而四氢化萘作为适当氢供体溶剂. 此外, 神华II技术采用悬浮床反应器和铁基催化剂, 具 有较高的褐煤液化能力. 此外, 在通过降解、水解、脱硫、脱氮、脱录和氢化直接液化褐煤的过程中检测到各种有用的产 物. 液化产物可以分成不同的组分类别, 例如芳环产物(前励青质, 沥青质和油)、氧化产物、环状产物和具有烃的烷醇分解 产物. 液化过程中涉及主要机制包括氧化, 自由基形成, 碳阳离子形成和烷醇分解. 在氢和催化剂存在下褐煤的裂解通常 遵循自由基机制褐煤液化的主要产物是单环产物, 包括苯酚、甲苯、对伞花烃等环状产物. 此外, 氧化机理通常产生更多 的氧化产物如羧酸等. 直接煤液化工艺如IGOR工艺在固定床反应器中运行在 $290 \sim 330^{\circ} \mathrm{C}$, 容量为 $200 \mathrm{t} / \mathrm{d}$, 而神华的DCL工 艺在悬浮床反应器中使用 $5 \%$ \% $\%$ 氢气转化 $92 \%$ 煤. 工业生产过程中使用的循环溶剂是 200 多种化合物的混合物, 包括蜡, 环烷烃, 狮类, 萠类和芳香族化合物等. 然而, 由于环数减少, 一些芳香族化合物(联苯)在 $455{ }^{\circ} \mathrm{C}$ 的加氢处理过程中发生开环 反应. 为了解决这个问题, 可使用在菜、菲、葱作为氢供体溶剂中含有环烷环的芳族化合物来促进液化.

本综述涵盖了各种褐煤和有效铁基催化剂及各种液化产物, 尤其涵盖有希望的催化剂, 并详细阐明所形成的化合物与 裂解反应之间的相关性, 且展示典型机理方案, 但褐煤和生物质的共液化机制尚未完全阐明, 因此需要进一步研究. 本文 有助于人们开发出更有效的褐煤(低级煤)液化过程催化体系.
\end{abstract}

关键词: 直接液化; 催化体系; 液化机理; 褐煤; 铁基催化剂

收稿日期: 2019-06-02. 接受日期: 2019-08-02. 出版日期: 2020-03-05.

*通讯联系人. 电子信箱：czhao@chem.ecnu.edu.cn

基金来源：国家重点研发计划(2016YFB0701100); 国家自然科学基金(21573075); 华师大崇明生态研究院计划 (ECNU-IEC-201902); 国家青年千人计划的资助。

本文的电子版全文由Elsevier出版社在ScienceDirect上出版(http://www.sciencedirect.com/science/journal/18722067). 